Canadian

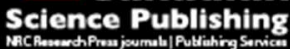

Canadian Journal of Zoology Revue canadienne de zoologie

\title{
Inuit Knowledge of Beluga Whale (Delphinapterus leucas) Foraging Ecology in Nunavik (Arctic Quebec), Canada
}

\begin{tabular}{|r|l|}
\hline Journal: & Canadian Journal of Zoology \\
\hline Manuscript ID & cjz-2015-0259.R1 \\
\hline Manuscript Type: & Article \\
\hline Date Submitted by the Author: & $30-$ Mar-2016 \\
\hline Complete List of Authors: & $\begin{array}{l}\text { Breton-Honeyman, Kaitlin; Trent University, Environmental and Life } \\
\text { Sciences; Trent University, Health, Environment, and Indigenous } \\
\text { Communities Research Group } \\
\text { Hammill, Mike; Maurice Lamontagne Institute, Dept Fisheries \& Oceans } \\
\text { Canada } \\
\text { Furgal, Christopher ; Trent University, Health, Environment, and } \\
\text { Indigenous Communities Research Group; Trent University, Indigenous } \\
\text { Environmental Studies Program } \\
\text { Hickie, Brendan; Trent University, Environmental and Life Sciences } \\
\text { Program }\end{array}$ \\
\hline Keyword: & $\begin{array}{l}\text { Beluga whale, Inuit Knowledge, <i }>\text { Delphinapterus leucas }</ \text { i }>, \text { ARCTIC }< \\
\text { Habitat, Feeding ecology }\end{array}$ \\
\hline \multicolumn{2}{|c}{} \\
\hline
\end{tabular}


2 Inuit Knowledge of Beluga Whale (Delphinapterus leucas) Foraging Ecology in Nunavik (Arctic Quebec), Canada

5 K. Breton-Honeyman, ${ }^{1,2}$ M. O. Hammill, ${ }^{3}$ C. M. Furgal, ${ }^{2,4}$ and B. Hickie ${ }^{1}$

6 kaitlinbh@gmail.com, chrisfurgal@trentu.ca, Mike.Hammill@dfo-mpo.gc.ca, bhickie@trentu.ca

$8{ }^{1}$ Environmental and Life Sciences Program, Trent University, Peterborough, Ontario,

K9J 7B8

$10{ }^{2}$ Health, Environment, and Indigenous Communities Research Group, Trent University,

$12{ }^{3}$ Maurice-Lamontagne Institute, Department of Fisheries and Oceans, Mont-Joli, Québec,

$14{ }^{4}$ Indigenous Environmental Studies Program, Trent University, Peterborough, ON K9J

16 Corresponding Author: Kaitlin Breton-Honeyman, P.O. Box 433, Inukjuak, QC, J0M

17 1M0, (819) 254-8667 (tel), (819) 254-8816 (fax), kaitlinbh@gmail.com 


\section{Inuit Knowledge of Beluga Whale (Delphinapterus leucas) Foraging Ecology in}

\section{Abstract}

23 The beluga whale (Delphinapterus leucas (Pallas, 1776)) is expected to be

24 influenced by changes in the environment. In Nunavik, the Arctic region of Quebec,

25 Nunavimmiut (Inuit of Nunavik) have depended on beluga for centuries developing an

26 extensive understanding of the species and its ecology.

27 Forty semi-directive interviews were conducted with Inuit hunters and Elders

28 from four Nunavik communities, who had a range of 28 to 47 years of beluga hunting

29 experience. Interviews followed an ethnocartographic format and were analyzed using a

30 mixed methods approach. Hunters most commonly reported prey species from the sculpin

31 (Cottidae), cod (Gadidae), salmon (Salmonidae), and crustacean families; regional

32 variations in prey as well as foraging habitat were found. Hunters identified significant

33 changes in body condition (i.e. blubber thickness), which were associated with

34 observations about the seasonality of feeding. The timing of fat accumulation in the late

35 fall and winter coupled with the understanding that Hudson Bay is not known as a

36 productive area suggest alternate hypotheses to feeding for the seasonal movements

37 exhibited by these whales. Inuit Knowledge of beluga foraging ecology presented here

38 provides information on diet composition and seasonality of energy intake of the beluga

39 and can be an important component of monitoring diet composition for this species into

40 the future.

41 An Inuttitut version of the abstract is available (Appendix A). 
42 Keywords: beluga whales, Inuit Knowledge, Delphinapterus leucas, Arctic, feeding

43 ecology

44 Écologie Alimentaire de la Baleine Béluga (Delphinapterus leucas) : Ce qu'on apprend du savoir Inuit au Nunavik (Région arctique du Québec), Canada

\author{
K. Breton-Honeyman, M. O. Hammill, C. M. Furgal, et B. Hickie
}

47 Résumé

$48 \quad$ Il est prévu que le béluga (Delphinapterus leucas (Pallas, 1776)) sera influencé

49 par des changements dans l'environnement. Au Nunavik, la région arctique du Québec,

50 les Nunavimmiut (Inuits du Nunavik) dépendent sur les bélugas depuis des siècles et ont

51 développé une connaissance approfondi de l'espèce et de son écologie.

52 Quarante chasseurs et Ainés Inuits, parvenant de quatre communautés du Nunavik

53 et ayant entre 28 et 47 ans d'expérience avec la chasse au béluga, ont participé à des

54 entrevues semi-structurées. Les entrevues ont suivi un format ethnocartographique et les

55 résultats soumis à une analyse d'approche méthodes mixtes. Les espèces de proie du

56 béluga identifiées les plus fréquemment par les chasseurs appartiennent aux familles du

57 chabot (Cottidae), de la morue (Gadidae), du saumon (Salmonidae), et des crustacés; des

58 variations régionales dans les espèces de proie et les habitats fréquentés relativement à la

59 quête de nourriture ont été identifiées. Les chasseurs ont aussi identifié des changements

60 importants dans l'état corporel (ex : l'épaisseur de la couche de graisse), qui étaient

61 associés à leurs observations du cycle saisonnier d'alimentation. Le cycle

62 d'accumulation de graisse à la fin de l'automne et à l'hiver, combinée avec la

63 compréhension que la Baie d'Hudson n'est pas connue comme une région productive,

64 suggère l'existence d'hypothèses alternatives à celle de la quête de nourriture pour 
65 expliquer les mouvements saisonniers de ces baleines. Les connaissances Inuites de

66 l'écologie alimentaire du béluga que nous présentons fournissent de l'information sur la

67 composition du régime alimentaire et de l'apport énergétique saisonnier du béluga, et

68 peuvent contribuer un élément important pour la surveillance du régime alimentaire de

69 cette espèce présentement, et dans le futur. 


\section{Introduction}

71 Understanding foraging ecology improves understanding of trophic structure,

72 relationships among species, and knowledge of how species may be affected by

73 environmental and ecosystem change. In the Arctic, changes in the environment are

74 altering food webs, with evidence of dietary shifts in seabirds (Gaston et al. 2003) and

75 pinnipeds (Chambellant et al. 2013; Crawford et al. 2015). These changes increase the

76 urgency of gathering data on foraging ecology to monitor changes or shifts over time,

77 although the opportunity for baseline data has likely already passed (Laidre et al. 2008).

78 Studying foraging ecology of Arctic cetaceans is inherently challenging given

79 their remote ice-covered environment, the limited time they spend at the surface, their

80 migratory nature, and the cost of research under these conditions. As a result, Arctic

81 wildlife research has generally focused on relatively few locations in the spring and

82 summer seasons (e.g. aerial surveys (Asselin et al. 2012)) (Gagnon and Berteaux 2009).

83 Beluga whales (Delphinapterus leucas (Pallas, 1776)) are medium-sized

84 odontocetes occupying a central role in the Arctic ecosystem. They have a circumpolar

85 distribution and are often associated with seasonally ice-covered waters, but are known

86 travel through areas of heavy ice cover (Suydam et al. 2001). The absence of a dorsal fin

87 is thought to be an adaptation to ice covered waters (Harington 2008).

88 Climate change forecasts predict that ice cover in the Arctic will decline, with

89 some areas formerly covered by the multi-year ice pack becoming seasonally ice free

90 (Stroeve et al. 2012). This provides an opportunity for Arctic species, whose distribution

91 is limited by ice, to expand their ranges, while more temperate species are also expected

92 to expand their ranges northwards (Laidre et al. 2008). Monitoring changes in distribution 
93 and foraging ecology among apex predators is one approach to monitoring climate

94 change impacts on the marine ecosystem (e.g. range expansion in northern reaches of

95 species distribution and changes in diet). Beluga are often considered generalist feeders,

96 with regional variations in diet (Loseto et al. 2009; Bailleul et al. 2012; Quakenbush et al.

97 2015), which may confer diet plasticity allowing them to adapt to these changes. Owing

98 to their wide distribution, and how well beluga are known, this species would appear to

99 be an excellent model to understand the impacts of climate change, because one would

100 expect that ecosystem changes might be reflected in changes in diet as more southerly

101 prey species move north.

102 Despite the extensive distribution of beluga, and the long history of research on

103 this species, there have been few studies on beluga diet in Canada (e.g. Vladykov 1946;

104 Doan and Douglas 1953; Loseto et al. 2009; Kelley et al. 2010; Marcoux et al. 2012) and

105 elsewhere (Kleinenberg et al. 1964; Tomilin 1967; Seaman et al. 1982; Heide-Horgensen

106 and Teilmann 1994; Quakenbush et al. 2015). Stomach content analyses, largely from

107 harvested whales, provided some of the earliest, and most recent, evidence of prey

108 species (Vladykov 1946; Sergeant 1962, 1973; Quakenbush et al. 2015). Molecular

109 methods such as, fatty acids, stable isotopes, and trace elements have provided indirect

110 evidence for diet, trophic level, habitat use and location, as well as how diet differs by

111 beluga size, sex and reproductive status (Loseto et al. 2007, 2008, 2009; Thiemann et al.

112 2008; Marcoux et al. 2012). Satellite-linked tagging studies have also increased our

113 understanding of feeding behavior. Dive profiles from tagged beluga have provided data

114 regarding target depth, feeding behaviour, and likely prey choice (Richard et al. 1998,

115 2001a; Kingsley et al. 2001; Bailleul et al. 2012; Citta et al. 2013; Hauser et al. 2015). 
116 Nunavimmiut (Inuit of Nunavik) have developed an extensive understanding of

117 the beluga whale and its ecology based on a long dependence on beluga, for their cultural,

118 health, and economic well-being that continues today (Van Oostdam et al. 2005). Inuit

119 adults in Nunavik participate in harvesting traditional or country foods, the greatest

120 percentage $(81 \%)$ of all regions in the Canadian Arctic, with beluga being the most

121 frequently consumed species of marine mammal (Blanchet and Rochette 2008; ITK

122 2008). Beluga inhabiting Nunavik coastal waters come from several different stocks,

123 some of which are considered endangered (Turgeon et al. 2011).

124 In the past, Inuit Knowledge (IK) has been considered anecdotal (Krupnik 2009),

125 or used as the basis for hypothesis generation for further scientific inquiry (e.g. Smith and

126 Stirling 1975), and not recognized as a legitimate source of data and knowledge (Simpson

127 2004). For beluga whales, however, IK has contributed greatly to our understanding of

128 foraging ecology, including seasonal variability, diet, and interactions among species

129 (Kilabuk 1998; Huntington et al. 1999; Mymrin et al. 1999; Huntington 2000; Doidge et

130 al. 2002) and it is clear that IK has great potential to further increase our understanding of

131 the foraging ecology of these animals.

132 In this paper, we present results from interviews with Inuit hunters and Elders

133 regarding foraging ecology of beluga whales in northern Quebec (Nunavik) Canada. Our

134 purpose was to document knowledge of diet composition and seasonal changes in body

135 condition of beluga whales from interviews to augment existing data. Given the

136 significant challenges to working in the North, such collaborations could be used to

137 develop a long-term program to monitor changes in prey species composition and the

138 effects of those changes as climate warming occurs. 


\section{Material and methods}

140 Semi-directive interviews (Huntington 1998) were conducted with expert beluga

141 whale hunters and Elders in the Nunavik communities of Kangiqsualujjuaq, Quaqtaq,

142 Ivujivik, and Kuujjuaraapik (Figure 1) in 2009 and 2010. These Inuit communities range

143 in population from 315 - 1517 and were selected because of their long history of beluga

144 harvesting and to have broad geographic coverage. In each community, a purposeful

145 sampling strategy (Creswell 2009) was used, selecting key interviewees with beluga

146 hunting and ecology expertise in particular. 'Expert' was defined by the number of times

147 and years in which a hunter hunted and recognition by community members as an

148 expert/knowledge holder (Davis and Wagner 2003). The structure for the interviews was

149 based on seasonal cycles starting with questions related to the ecology of the species from

150 when beluga are first seen in the year (e.g. spring migration). Throughout the interviews,

151 questions were focused around migration and important habitat areas for different life

152 history traits. Topics included, but were not limited to: migration, body condition,

153 foraging ecology, predation, breeding, calving and behaviour. Particular attention was

154 also given to how any of these aspects have changed according to each participant's

155 frame of reference. The results presented here are part of an extensive research project -

156 Nunavimmiut Knowledge of Beluga - however, only the information pertaining to

157 feeding ecology is presented here. Interviews also contained a participatory mapping

158 component where participants documented beluga behaviour and habitat use (e.g.

159 foraging locations) by drawing on local and regional maps (Gadamus and Raymond-

160 Yakoubian 2015). A prey species guide, in Inuttitut and English, was also created

161 specifically for the project interviews to allow for more detailed identification of prey 
162 (McLeod et al. 2009). Interviews were conducted in the participants' chosen language via

163 the assistance of an English / Inuttitut interpreter/translator and were audio recorded.

164 Participants identified prey species, foraging behaviour and locations, and timing

165 of foraging activity through several different observational methods. Prey species were

166 identified both by direct observations of feeding, and observations of stomach contents of

167 killed animals, and indirectly through observations of foraging behaviour. Only species

168 that were confirmed in subsequent discussions with participants are included in the

169 results. Foraging behaviour was identified as the active pursuit of prey, or indirect

170 behaviours such as beluga circling prey and pushing schools of fish together and pushing

171 them towards shore (e.g. capelin (Mallotus villosus (Müller, 1776))).

172 A mixed methods approach for data analyses was taken, using quantitative

173 statistical analyses to further explore the results of qualitative analyses (Creswell 2009).

174 Interviews were first transcribed and the maps of participants' observations of beluga

175 were digitized into a geographic information system, ArcGIS 9.2 (ESRI, 2006). Once

176 interviews were transcribed and verified, they were imported into the qualitative

177 analytical software package NVivo 8 (QSR International, 2008). Thematic content

178 analysis was conducted on the transcripts in that themes were created using the topics

179 from the interview guide as well as other topics that emerged in the interviews (Creswell

180 2009). Through this process it was possible to consolidate and summarize participants'

181 responses to different topics and determine patterns of responses among participants. In

182 the qualitative presentation of responses the terms 'a couple', 'several', and 'most/

183 majority of are used consistently throughout the results presentation and refer to 
184 observations and statements that were noted by ' 2 ', ' $3-5$ ', and ' $50 \%$ or more' of the

185 participants, respectively.

186 Frequencies of participant responses were analyzed by thematic categories to

187 statistically to examine differences among communities. Descriptive statistics were used

188 to illustrate the distribution of participant observations presented in the thematic analysis.

189 Non-parametric statistical tests were prioritized given small sample sizes. For tests that

190 are sensitive to variance, homogeneity of variance was tested prior to analysis. A

191 Kruskal-Wallis test was used to examine differences in participants' age and experience

192 by community and a Wilcoxon matched pairs signed ranks test was used for observations

193 of body condition (i.e. the continuous data). Fisher's Exact test was used for

194 observational count data (e.g. prey species and habitat type) by community. Results were

195 defined as statistically significant at $p<0.05$. Analyses were performed using JMP 11.0.0

196 (SAS Institute Inc., USA).

197 Following the digitization of the maps, common beluga features (e.g. feeding

198 locations) drawn by participants were combined and kernel density estimation was

199 applied to aggregate collective responses and include a source of uncertainty for all

200 features (Worton 1989). Maps presented therefore represent the collective responses

201 from either a specific community or all communities.

$202 \quad$ Preliminary results were verified and validated (Creswell 2009) with

203 Kangiqsualujjuaq, Quaqtaq, Ivujivik and Kuujjuaraapik participants and final results were

204 reported through meetings open to the whole community during 2010 and 2011. Some

205 topics particularly benefited from validation. For example, changes in blubber thickness

206 were discussed in all of the verification and final reporting meetings and through group 
207 discussions consensus was reached in each community regarding an average blubber

208 thickness and the associated time of year. Similarly, in some cases the consensus around

209 stomach fullness was developed either during the verification or final reporting

210 workshops.

\section{Results}

\section{Participant Information}

214 A total of 40 participants were interviewed in 4 communities. Participants had a

215 median age of 63 years (range $34-86$ years old) (Table 1). The age of the participants

216 was not statistically different between communities (Kruskal-Wallis, $\mathrm{df}=3, \chi^{2}=5.40, p=$

217 0.14). The majority of participants were male; less than $20 \%$ were female. The median

218 time that participants had spent in their hunting-area was 61 years and ranged between 48

219 years in Ivujivik to 67 years in Kangiqsualujjuaq. No difference in length of interviewee

220 experience was observed between communities (Kruskal-Wallis, $\mathrm{df}=3, \chi^{2}=5.07, p=$

221 0.17). The majority of participants noted that they began hunting beluga when they were

222 young teenagers, but had followed older hunters for years prior to actually hunting.

223 Therefore each participant had, on average, over 40 years of experience in his or her area.

224 On average $86 \%$ of the participants were active hunters, with the lowest proportion in 225 Kangiqsualujjuaq $(73 \%, n=11)$ and the highest proportion in Ivujivik $(100 \%, n=8)$.

226 The size of community beluga hunting areas (i.e. all individual beluga hunting

227 areas combined) varied between communities. Hunters in Ivujivik and Quaqtaq

228 identified the smallest hunting areas, while Kangiqsualujjuaq and Kuujjuaraapik hunters

229 used larger areas (Table 1). For all communities with the exception of Kuujjuaraapik, the 
230 feeding areas were larger than the beluga hunting areas. The time of year beluga are

231 observed varied by community. While all communities observed beluga throughout the

232 year, Quaqtaq and Ivujivik hunters observed large numbers during the spring and fall

233 migrations, whereas Kuujjuaraapik hunters observed whales intermittently throughout the

234 summer. Kangiqsualujjuaq hunters observed beluga during the spring and fall migrations,

235 though to a lesser extent than Quaqtaq and Ivujivik, and also intermittently throughout

236 the summer.

237 Prey Species

238 Nunavimmiut identified a diverse range of fish and invertebrate prey species

239 (Table 2; Figure 2). Participants were able to identify prey to either the genus or species

240 level, depending on the experience of the participant, the level of digestion of stomach

241 contents, and the conditions during harvest. To increase sample sizes, prey species were

242 grouped by family for comparison among communities. A full list of species identified is

243 included in Table 2. Sculpin (Cottidae), cod (Gadidae), salmon (Salmonidae) and

244 crustaceans were more frequently reported by participants as known beluga prey than

245 smelt (Osmeridae), sandlance (Ammodytidae) and herring (Clupeidae). Sculpins, cods,

246 and crustaceans were identified in all communities. Two fish species, shorthorn sculpin

247 (Myoxocephalus scorpius (L., 1758)) and Greenland cod (Gadus ogac (Richardson,

248 1836)), were identified as beluga prey in all communities. Direct observation of beluga

249 feeding on sculpins and cod was identified by $55 \%$ and $53 \%$ of all participants,

250 respectively. Although no significant difference was found among communities for

251 sculpins or cod, they were more commonly reported in Ivujivik (75\% for both species)

252 and Kuujjuaraapik (70\% and $60 \%$ of participants respectively). Capelin was identified in 
253 all communities, except Quaqtaq, which reported sand lance (Ammodytes sp.). It was

254 thought that it was likely American sand lance (Ammodytes americanus (DeKay, 1842))

255 based on the type of behaviours observed (i.e. close to shore). Sand lance are present

256 when the ice first breaks up and very early in the summer, the middle of July, as well as

257 on the beach in August. Capelin was reported by $24 \%$ of the participants from the other

258 three communities with no significant regional variation. Participants in Ivujivik and

259 Kuujjuaraapik said that capelin is among the most important prey items for beluga and

260 Ivujivik hunters noted the particular importance of capelin during the fall when they are

261 present in large schools. Kuujjuaraapik and Kangiqsualujjuaq participants also observed

262 new species of fish in their areas due to warming waters but did not identify the species.

263 "Ya, there was usually the fish that usually are from this area that I used to see inside the

264 stomach, but nowadays with the warming of the... Arctic we're starting to have different

265 fish inside their stomach" (Willie Tooktoo).

266 Some regional differences were reported. For example, there was significant

267 variation in the reporting of Salmonidae within Nunavik (see Table 2). Hunters in

268 Kangiqusluajjuaq ( $73 \%$ of participants) and Quaqtaq (55\% of participants) reported

269 Arctic char (Salvelinus alpinus alpinus (L., 1758)) more frequently than Ivujivik or

270 Kuujjuaraapik hunters (Fisher's Exact test, $p=0.00002$ ). One participant in Ivujivik

271 reported Arctic char but this could not be confirmed though other participants agreed that

272 it was possible. "Dolly varden" (Salvelinus malma malma (Walbaum, 1792)) was

273 identified as a beluga prey in both Kangiqsualujjuaq and Kuujjuaraapik but the current

274 known distribution of this species makes this unlikely (Scott and Crossman 1973). It is

275 more likely that it was an Arctic char and brook trout (Salvelinus froninalis (Mitchill, 
276 1814)) hybrid (Hammar et al. 1991; Glemet et al. 1998). Quaqtaq hunters noted that

277 shorthorn sculpin, Arctic char, and shrimp are the most common beluga prey, particularly

278 in the winter. Hunters in Kuujjuaraapik noted that there are two types of whitefish

279 (Coregonus), inshore and offshore, and that both types are important beluga prey species.

280 High seasonal variability in beluga prey occurred for Arctic char, capelin, and

281 sand lance. Participants in both Quaqtaq and Ivujivik, however, observed that location

282 accounted for more variation in beluga diet than season.

283 Foraging Habitats and Locations

284 Hunters identified beluga feeding locations throughout Nunavik coastal waters.

285 Sixty-five percent of participants spoke about specific habitat types, noting that beluga

286 forage in rivers, bays, onshore, and offshore (Table 3) and identified these foraging areas

287 on maps (Figure 3 a-d). Rivers were reported much more often as feeding locations

288 (73\%) throughout Nunavik, while bays (31\%), shores (23\%), and offshore areas (12\%)

289 were identified less frequently (Table 3).

290 There is regional variation in habitats used for foraging (Table 3). Participants

291 from Kangiqsualujjuaq, Quaqtaq and Kuujjuaraapik who discussed habitat types

292 mentioned rivers significantly more often than participants in Ivujivik, where rivers were

293 not mentioned in the context of foraging locations. Ivujivik hunters mentioned bays more

294 frequently than Kuujjuaraapik hunters, who did not mention bays at all (Fisher's Exact

295 test, $p=0.005)$. Ivujivik and Quaqtaq participants similarly reported that beluga feed

296 along the shore or coast near their communities (40 and 43\%, respectively). Feeding

297 along shore, particularly as beluga arrive, was also mentioned in Kuujjuaraapik

298 specifically in relation to feeding on capelin. Quaqtaq hunters who discussed foraging 
299 habitats said that beluga feed in offshore areas (29\%) (see Figure 3 a-d for all feeding 300 locations identified), though this was not significantly different from other communities.

301 It was also noted, particularly in Quaqtaq and Kuujjuaraapik, that beluga move between

302 inshore and offshore areas, probably associated with tide-related feeding opportunities.

303 "At the low tide they would go down, feed off shore and high tide they would come in

304 again" (Alec Tuckatuck). Strong currents and upwellings are important for feeding.

305 "Beluga depend on currents very much for feeding”(David Okpik). The noted

306 association with currents was particularly common in Kangiqsualujjuaq and was reported

307 by $55 \%$ of participants.

308 In August and September, Arctic char and Atlantic salmon (Salmo salar (L.,

309 1758)) migrate upriver giving rivers greater importance as foraging habitat.

310 Communities along Hudson Strait, however, observed less feeding during this time.

311 Quaqtaq participants reported that beluga do not feed while they are migrating,

312 particularly during the spring migration, and feed mainly in their wintering, but also their

313 summering areas. Beluga that remain in Hudson Strait during the summer are observed

314 feeding in rivers, particularly those southeast of Kangiqsujuaq. They are reported to be

315 most likely feeding on sand lance and Arctic char. Winter feeding was noted to take

316 place in Hudson Strait and by Killiniq at the tip of the Quebec - Labrador peninsula

317 (Figure 1).

318 Several hunters in Kangiqsualujjuaq (27\%) and two in Quaqtaq (18\%) noted

319 differences in foraging associated with gender or reproductive status. In

320 Kangiqsualujjuaq, participants reported that males generally feed farther offshore than

321 females and calves. During the final reporting meeting in Quaqtaq females were reported 
322 to often leave their calves at the river mouths of known 'good char rivers' during the

323 summer while they feed on char. Also in Quaqtaq, a hunter reported females exhibiting

324 cooperative feeding behaviour by these rivers to feed their calves.

$325 \quad$ One time a bunch of us we were watching a calf being fed by the parent whales.

326 During the month of July we were going fishing here and we saw a calf there (in the

327 rivers near Kangiqsujuaq, Innangajuit - char river). We stopped for lunch and we

328 saw a whole bunch of whales coming from the ocean into the bay. They were coming

329 in this way and there were calves here, beluga calves. When they were coming we

330 didn't notice any unusual activity, but then a few minutes later we started finding out

331 they're drawing in a school of Arctic char fish right to their calf. And they circled

332 and just let the calf eat from that. And every time the pool of fish tried to get away

333 they were diverting them right to where the calf was. It was something else. The most

$334 \quad$ unusual moment I have watched in the beluga, how they worked together. And these

335 were about maybe five, six whales working together bringing in the pool of Char

336 fish! We were witnessing very clearly what was happening there. (Harry Okpik)

\section{Seasonality of Foraging}

338 Participants also spoke about the time of year beluga forage in their hunting areas.

339 All communities agreed that beluga feed intensively during the winter and less so during

340 the summer. "All year 'round even in the winter time the beluga are here in the open

341 water. All over around here they're going like back and forth the whole winter... in

342 Hudson Strait. They're feeding and they gain weight around here" (Quitsaq Tarriasuk).

343 Feeding during the late summer (July and August) was mainly observed for communities

344 with large runs of fish nearby, such as Kangiqsualujjuaq and Kuujjuaraapik. "They wait 
345 for the blueberries to turn blue and they come along to the mouth of the river. That's

346 when the fish come in." (Sappa Fleming). While some participants reported that there is

347 some feeding occurring during migration, others from each of the communities which

348 observed beluga during migration said that beluga are feeding very little during that time.

349 Observations of feeding during migration were frequent in Quaqtaq (73\%). It was also

350 noted that there is more feeding during the fall than the spring migration.

351 In addition to prey identification, hunters observations of stomach contents

352 provided indirect observations about the amount of feeding. Hunters in all communities

353 looked in beluga stomachs (73\% of all participants), and although it varied by community

354 this variation was not significant (Table 4). The percentages reported represent the

355 number of hunters interviewed who have looked at beluga stomachs but most hunters

356 have done so on many occasions. In the past, when beluga stomachs were used as floats

357 for harpoons, Nunavimmiut observed stomach contents more commonly. For those

358 communities observing beluga stomachs during their migration most observed them to be

359 quite full during the spring migration and quite empty during the fall migration (Table 4).

\section{Body Condition}

361 Participants were asked about the general body condition of beluga, specifically

362 blubber and skin, with attention to seasonal variation and overall beluga health. There

363 were individuals in each community who observed pattern of beluga being fattest in late

364 winter and early spring and thinnest during the fall. In Quaqtaq and Ivujivik the pattern

365 was strong and reported by $100 \%$ and $75 \%$ of participants, respectively. In

366 Kangiqsualujjuaq and Kuujjuaraapik the pattern was less noticeable, reported by 55\% and

$36710 \%$ of participants, respectively. Given the strength of this pattern in the Hudson Strait 
368 communities, participants from Quaqtaq and Ivujivik were further asked if they could

369 quantify the change in blubber thickness by estimating average thickness at the same

370 location (behind the head on the dorsal side) at different times of the year. Based on the

371 estimates that hunters from Quaqtaq and Ivujivik provided, beluga lose $5 \mathrm{~cm}$ (median) of

372 blubber thickness between the spring and the fall (Wilcoxon signed rank matched-pair

373 test, $S=-33.00, n=11, p=0.001)$. The median spring blubber thickness reported was 11

$374 \mathrm{~cm}$ (range: $6.3-20 \mathrm{~cm}$ ) and the median fall blubber thickness reported was $4 \mathrm{~cm}$ (range: 1 -

$3759 \mathrm{~cm}$ ) (Figure 4). During the final reporting meeting in Quaqtaq it was cautioned that

376 there can be considerable variation between whales, and that blubber thickness is

377 dependent on other factors such as size and whether it is a migratory or resident whale.

378 Observations of these changes from all communities are summarized in Table 5.

379 Observations of body condition were associated with whether beluga float or sink

380 when killed. Beluga usually float in the late winter and spring, when they have thick

381 blubber, and sink in the fall when they are thinner (Kangiqsualujjuaq, 45\%, Quaqtaq,

$38245 \%$ and Ivujivik, 34\%). "That's (March) when they don't sink anymore. Like if you

383 shoot them they'll float. Blubber is so thick they don't sink' (Joshua Annanack). When

384 discussing fall hunting it was frequently stated that a different hunting approach is

385 necessary to retrieve beluga, such as hunting in shallow waters or with a heavy hook. It

386 was emphasized, especially during the final reporting trip, that it is important to not over

387 simplify this pattern of weight change because there are beluga that do not follow this and

388 will sink in the spring or float in the fall and in general, blubber thickness is more

389 variable in the fall. Several interviewees also noted an overall trend, saying that beluga

390 are fatter than they used to be, particularly in the fall. Hunters in Ivujivik associated 
391 these changes in body condition with behavioral changes, noting that beluga are more

392 'skittish' (i.e. cautious) in the fall. Similar behavioural observations were made by

393 Kuujjuaraapik hunters but were associated with moulting rather than changes in body

394 condition.

395 In Quaqtaq, two participants discussed the characteristics of blubber, noting that

396 the blubber is yellower, oilier (containing more liquid), and denser in the spring. The

397 changes in the characteristics of the blubber were also discussed in the final reporting

398 meeting and it was noted that beluga have more oil in the summertime but are not

399 necessarily more fat and that beluga fat is more dense in the spring than in the fall. In the

400 final reporting meeting it was added that grey whales (i.e. juveniles) tend to be very oily.

402 Discussion

403 Using a mixed methods approach provided an effective way to analyse IK to add

404 to the existing knowledge base regarding beluga whale diet composition, foraging time

405 and location, and seasonal changes in body condition in Nunavik waters.

406 Participants had, on average, 40 years of beluga hunting experience within their

407 hunting areas, thus differences among communities, in diet, condition and behaviour are

408 likely reflecting real differences in regional or seasonal activity. When whales are nearby

409 communities also impacts hunters' observations and varies regionally. For example,

410 although all communities reported some observations of beluga throughout the year the

411 two Hudson Strait communities (Quaqtaq and Ivujivik) primarily observe beluga during

412 their spring and fall migration whereas Kangiqsualujjuaq hunters observe a migration of

413 fewer animals and travel to both Quaqtaq and Killiniq for hunting during the larger 
414 migration. All communities observe beluga throughout the summer though the

415 observations are sporadic in all communities except Kuujjuaraapik, which sees beluga

416 throughout the summer.

\section{Prey Species}

418 In total, 21 species were identified as beluga prey by hunters, with sculpin, cod,

419 salmon, trout, whitefish and crustaceans dominating diets, which was similar to that

420 described in earlier unpublished traditional ecological knowledge studies from this region

421 (McDonald et al. 1997; Doidge et al. 2002; Lee et al. 2002). According to scientific

422 studies of more northern populations such as the Beaufort Sea, Cumberland Sound, and

423 Greenland (Heide-Jorgensen and Teilmann 1994; Loseto et al. 2009; Marcoux et al.

424 2012; Table 6), beluga in Nunavik consumed sculpin, cod, salmon and crustaceans more

425 often than Arctic cod (Boreogadus saida (Lepechin, 1774)) (Table 2). Arctic cod was

426 identified as beluga prey by Salluit hunters in a previous TEK study (Lee et al. 2002), but

427 only a single hunter from both Kangiqsualujjuaq and Ivujivik mentioned Arctic cod

428 during this study. Hunters did not indicate a change in diet related to cod and the

429 regional differences are more likely related to a north-south cline in prey availability.

430 Capelin, which was identified in all but one community, and qualitatively described as a

431 dominant prey species, has also been identified as dominant prey for Western Hudson

432 Bay beluga (Kelley et al. 2010), as well as in beluga from the St. Lawrence River Estuary

433 (Vladykov 1946). One of the predictions of climate change is that there will be fewer

434 northern prey species, such as Arctic cod, and more temperate species, such as capelin,

435 may replace them. However, it is not known whether capelin has always been an

436 important prey species for beluga in eastern Hudson Bay or whether that is a recent shift 
437 as has been shown for thick-billed murres (Uria lomvia (L., 1758)) in northern Hudson

438 Bay (Gaston et al. 2003) and hypothesized for the Cumberland Sound beluga (Marcoux et

439 al. 2012) and ringed seal (Pusa hispida (Schreber, 1775)) populations (Chambellant et al.

440 2013). Although the observed importance of capelin could suggest that temperate species

441 may be moving in with warming sea temperatures, Watts and Draper (1986) documented

442 beluga preying upon capelin in western Hudson Bay over 30 years ago indicating that

443 capelin is not a new arrival, at least on that coast of the bay. Hunters in the more

444 southern communities (i.e. Kangiqsualujjuaq and Kuujjaraapik) noted that they are

445 observing new types of fish though there were few other noted changes in prey. This

446 suggests it may be related to the latitudinal gradient though there are alternate

447 possibilities (e.g. species introductions).

448 Regional differences characterized beluga diet in Nunavik, with only two species,

449 Greenland cod and shorthorn sculpin, reported throughout the region (Arctic char was the

450 most reported prey in Kangiqsualujjuaq and capelin was qualitatively described as

451 dominant in Ivujivik and Kuujjuaraapik). The greatest abundance of Salmonidae species

452 (7), was reported in Kangiqusalujjuaq, which is also the area where many of the salmonid 453 species distributions overlap (Scott and Crossman 1973). Other populations of beluga

454 inhabiting the same latitude, such as Cook Inlet and Bristol Bay beluga, also feed on a

455 variety of salmonids; at least 3 of the 5 and all of the different species of salmon found in

456 that area, respectively (Hobbs et al. 2008; Goetz et al. 2012; Quakenbush et al. 2015). In

457 other communities, for example Ivujivik, no hunters reported observations of beluga

458 preying on salmonids, though it was noted that beluga could be preying upon Arctic char.

459 For a species to become a common prey item two things must occur; beluga and prey 
460 must regularly overlap in space and time. For a fish species to be a known prey item, in

461 this study, the beluga either needed to be harvested or observed feeding. Therefore, what

462 we can learn about diet using IK depends on the overlap in the distribution and timing of

463 beluga and potential prey species, the hunter observations and timing of the harvest.

464 Though Arctic char are distributed throughout Nunavik and were historically present in

465 Great Whale River (Scott and Crossman 1973), during more recent sampling along

466 Hudson Bay, char were not found south of the Innuksuac River (Morin et al. 1980). This

467 may explain why char were not reported beluga prey by Kuujjuarapik hunters or it may

468 be related to the time of year beluga are present in Eastern Hudson Bay. In the more

469 eastern communities, Quaqtaq and Kangiqsualujjuaq, beluga are observed during their

470 fall migration at the same time of year there are large river runs of anadromous fish (Scott

471 and Crossman 1973), likely leading to the dominance of char reported. However there

472 were participants who specifically noted that changes in location account for more

473 change in beluga diet than season, though it is difficult to disentangle the two factors

474 given beluga's strong seasonal movements.

\section{Foraging Habitats and Locations}

476 Hunters have observed beluga using a range of habitats (e.g. rivers, bays, offshore,

477 and nearshore) for foraging throughout Nunavik, with rivers identified most by

478 participants from all communities, except for Iuvjivik. Rivers, particularly in the fall, are

479 likely important due to anadromous fish runs (e.g. Southeast Baffin and Alaskan beluga

480 populations for Arctic char and salmon, respectively) (Kilabuk 1998; Huntington et al.

481 1999) therefore community location likely influences reported habitat use. For example,

482 in Ivujivik, where there are few large rivers, hunters reported beluga foraging in bays 
483 more commonly than hunters in Kuujjuarapik, where there are several large rivers. The

484 observation of beluga feeding along the shore in most of the communities likely coincides

485 with capelin spawning (late June - August in the North Atlantic) (Davoren and

486 Montevecchi 2003) and also when sand lance are nearshore (late summer) (participants

487 and Robards and Piatt 1999). The observation, particularly by Quaqtaq participants, that

488 beluga are feeding in offshore areas is also corroborated by telemetry data for this beluga

489 population and others (Richard et al. 2001b; Bailleul et al. 2012). For example, in Lewis

490 et al. (2009) beluga whales spent $76 \%$ of their time in areas greater than 15 kilometers

491 from shore and traveled to deep-water troughs $(600 \mathrm{~m})$ in the Labrador Sea in the winter,

492 most likely associated with foraging activities. Observations of movement between

493 offshore and inshore areas are thought to be associated with feeding by Nunavimmiut,

494 which has also been hypothesized for these and other populations by biologists (Richard

495 et al. 2001a; Bailleul et al. 2012). Tagging studies in the western Arctic have shown that

496 beluga travel into pack ice much greater distances from shore than previously thought

497 (Suydam et al. 2001; Citta et al. 2013; Hauser et al. 2014), supporting the argument that

498 beluga may be using heavy pack ice, perhaps for predator avoidance in addition to

499 feeding. These tagging studies and interviewee observations support that beluga use

500 offshore habitats as well as estuarine and coastal areas.

501 Hunters in half of the communities referenced gender and reproductive status

502 when discussing habitat use for foraging. For example, Kangiqsuluajjuaq hunters noted

503 that males generally feed farther offshore and on larger fish than females and calves.

504 Segregation based on gender, size and reproductive status has also been documented in

505 the Beaufort Sea (Loseto et al. 2006). 


\section{Seasonality of Feeding}

$507 \quad$ Hunters shared observations of beluga foraging throughout the year and

508 participating communities agreed that feeding activity peaks during the winter. This

509 comes from direct observations of feeding, when Inuit used to hunt beluga during the

510 winter. This practice is less common now due to changes in the environment and

511 management regulations. Feeding in the winter is also inferred from observation that

512 beluga gain mass during the winter. Though many populations of beluga feed most

513 intensively during the spring and summer (e.g. Alaskan stocks) there are other

514 populations for which fall and winter are the seasons of greatest foraging activity (e.g.

515 Koski et al. 2002) (Mosnier et al. 2010). In communities near migration routes,

516 interviewees reported that beluga feed very little while they migrate, particularly during

517 the spring. Interviewees reported that feeding activity is less intense in summer, and that

518 it increases in fall. These observations are similar for those of High Arctic beluga where

519 very little feeding activity was observed in summer estuarine areas (Koski et al. 2002).

520 Participants also noted seasonal fluctuations in prey, particularly for those prey species

521 that have stages in their life cycle that bring them closer to shore or into rivers (e.g. Arctic

522 char, capelin, and sandlance). Interviewees also noted seasonal fluctuations in habitat use

523 (e.g. importance of river during the fall).

524 Seasonal observations of foraging activity are also supported by the examination

525 of stomach contents, which was common practice among the majority of hunters

526 interviewed (73\%). Variation in the practice was related to community differences in

527 harvest conditions. For example the spring harvest in Quaqtaq is usually done from the

528 ice edge where time is limited and therefore fewer people look at stomach contents. In 
529 the verification and final workshops with participants, consensus was developed and

530 generally indicated that beluga migrating in the spring have fuller stomachs while in the

531 fall more stomachs were empty, which participants thought was reflective of the amount

532 of feeding that took place prior to migration.

\section{Body Condition}

534 The annual changes in body condition suggest that beluga go through a

535 considerable seasonal change in blubber thickness, gaining in the winter and losing

536 throughout the rest of the year, primarily during migrations. Hunters from Kuujjuaraapik,

537 thought the reduction in blubber thickness after moulting was due to high energy

538 expenditures during breeding and calving. To quantify the changes, Quaqtaq and Ivujivik

539 hunters reported blubber thickness during spring and fall migrations and a matched paired

540 analysis was performed. The timing of fat accumulation coupled with the understanding

541 that Hudson Bay is not known as a productive region (Stewart and Lockhart 2005),

542 indicates that there are likely other factors for the migration into Hudson Bay and lends

543 support to alternate hypotheses. For example the elevated temperatures and low salinity

544 conditions of estuaries in Hudson Bay provide conditions for moulting (St Aubin et al.

545 1990; Koski et al. 2002). Alternately, this movement could be related to predator

546 avoidance, given that killer whales (Orcinus orca (L., 1758)) have only recently become

547 more numerous in Hudson Bay (Higdon and Ferguson 2009; Hammill 2013)

$548 \quad$ Seasonal differences in body condition have been observed in Baffin Island

549 populations of beluga (Kilabuk 1998) and Alaskan hunters also noted similar

550 observations of beluga being fattest in the spring (the 'winter coat') and thinnest in the

551 fall (Huntington et al. 1999). This seasonal pattern also parallels other marine mammals 
552 such as polar bears (Ursus maritimus (Phipps, 1774)) which have the highest adipose

553 stores at the end of the winter (Derocher et al. 2004). Given the pervasiveness of the loss

554 in mass, hunters inferred that it is related to the energetic cost of migration and the lack of

555 foraging in the summer, though given the significant cost of lactation for females

556 (Matthews and Ferguson 2015), the change may be related to multiple factors. For

557 example, the warmer waters of the summering areas require less blubber for

558 thermoregulation and therefore beluga do not forage as extensively at that time of year.

559 The changes are related to lactation may account for some of the individual variation (but

560 only in females) observed by hunters. These seasonal changes in body condition have

561 potentially significant implications for bioenergetics (e.g. energy budget, heat loss and

562 feeding rate).

563 Some caution is needed when interpreting the quantitative results. The

564 methodological approach (i.e. semi-directive interviews) meant that although participants

565 spoke to the same general topics they did not necessarily speak to the same points. In

566 many cases analysis was done on all responses received regardless of whether they were

567 the result of a specific question. For example, because participants were not consistently

568 and specifically asked about whether beluga float or sink when harvested at different

569 times of the year the proportion of participants who would have contributed to that topic

570 was under-represented.

571 Although we were able to quantify much of the information collected, in some

572 instances observations were not particularly supported by quantitative results but were

573 strongly supported by the qualitative. For example, capelin was only reported by $24 \%$ of

574 participants overall, participants in the Hudson Bay communities clearly emphasized their 
575 importance as beluga prey. This qualifying of the quantitative results, and vice-versa,

576 speaks to the importance and strength of a mixed methods approach (Fetters et al. 2013).

577 Results were greatly improved by the verification and validation process conducted in

578 workshops. By reviewing the information that had been collected during the interviews

579 we were able to correct, clarify and further describe results. Finally, these results can only

580 truly represent the participating hunters' experiences and knowledge, and not the

581 community's knowledge as a whole and any extrapolation needs to be done with caution.

582

583 Inuit Knowledge provides a complementary approach to other dietary methods

584 (i.e. stomach contents, stable isotope and fatty acid analysis); each approach is limited by

585 the realities of methodology and the challenges of research in the Arctic (Bowen and

586 Iverson 2012). The year-round and long-term nature of the observations and experiences

587 that hunters shared about beluga whale foraging ecology adds considerably to beluga

588 whale foraging ecology literature, specifically contributions regarding diet composition,

589 foraging behaviour, locations, and seasonal body changes in condition. Documentation of

590 Nunavik IK of foraging ecology also provides reference data that can be used for

591 monitoring and detecting change, as well as for the conservation of this species by

592 providing information that can be used to develop mitigation measures for industrial

593 activity such as commercial fisheries and marine development (Gavrilchuk and Lesage

594 2014). This study demonstrates that IK can greatly add to current knowledge and be

595 incorporated into long-term monitoring programs (that identify prey in stomachs and

596 listen to local hunters) to monitor for changes in the marine ecosystem (e.g. appearance

597 of more temperate species). More specifically, the information on diet can contribute to a 
598 circumpolar spatial model of diet composition for beluga whales able to monitor

599 latitudinal and temporal shifts in prey. With the communities as monitoring sites and the

600 hunters as researchers a cost effective, efficient, and experienced monitoring program

601 could be developed.

602

603 Acknowledgements

604 First and foremost the authors gratefully acknowledge the forty expert hunters and Elders

605 who made this work possible - Kuujjuaraapik: Jobie Abraham, Jimmy Paul Angutiguluk,

606 Betsy K. Crow, Alec Fleming, Louisa Fleming, Sappa Fleming, Willie Tooktoo, Alec

607 Tuckatuck, Moses Weetaltuk, Caroline Weetaltuk; Ivujivik: Moses Ainalik, Peter Ainalik,

608 Sirqualuk Ainalik, Jimmy Audlaluk, Lucassie Kanarjuaq, Charlie Paningajak, Quitsaq

609 Tarriasuk, Saviarjuk Usuarjuk; Quaqtaq: Susie Aloupa, George Angnatuk, Peter Aupaluk,

610 Willie Jararuse, Louisa Kulula, Harry Okpik, David Okpik, Charlie Okpik, David Oovaut,

611 Johnny Oovaut, Eva Tukkiakpik; Kangiqsualujjuaq: Johnny G. Annanack, Joshua

612 Annanack, Bobby Baron, Christina Baron, Willie Emudluk, Tommy George Etok, Tivi

613 (David) Etok, Lucas Etok, Willie Etok, Paul Jararuse, Tommy Unatweenuk. The authors

614 also wish to thank the late Dr. Bill Doidge who was instrumental in this project. This

615 manuscript was greatly improved by regional reviews by Gregor Gilbert (Makivik

616 Corporation) and Mark O'Connor (Nunavik Marine Region Wildlife Board (NMRWB)),

617 and comments and suggestions from Lori Quakenbush and an anonymous reviewer. We

618 also thank Kristeen McTavish and Sarah Aloupa for translation, Matt Toll for assistance

619 with mapping, and Melanie Lemire for statistical advice. An earlier version of this paper

620 was presented at the $19^{\text {th }}$ Biannual Conference on the Biology of Marine Mammals in 
621 2011. KBH thanks the Garfield Weston Foundation, NSERC, and Canadian Scholarship

622 Trust Foundation for support during her graduate work. We thank International Polar

623 Year, Northern Scientific Training Program, Department of Fisheries and Oceans, and

624 Trent University for funding support.

625

626 References

627 Asselin, N.C., Barber, D.G., Richard, P.R., and Ferguson, S.H. 2012. Occurrence, 628 distribution and behaviour of beluga (Delphinapterus leucas) and bowhead 629 (Balaena mysticetus) whales at the Franklin Bay ice edge in June 2008. Arctic, 630 65(2): 121-132. doi: 10.14430/arctic4194.

631 Bailleul, F., Lesage, V., Power, M., Doidge, D.W., and Hammill, M.O. 2012. Differences 632 in diving and movement patterns of two groups of beluga whales in a changing Arctic environment reveal discrete populations. Endanger. Species Res. 17: 2741. doi: 10.3354/esr00420.

Blanchet, C., and Rochette, L. 2008. Nutrition and food consumption among the Inuit of Nunavik. Nunavik Inuit Health Survey 2004, Qanuippitaa? How are we? Quebec: Institut national de santé publique du Québec (INSPQ) \& Nunavik Regional Board of Health and Social Services (NRBHSS). Available from http://www.inspq.qc.ca [accessed 6 October 2015].

640 Bowen, W.D., and Iverson S.J. 2012. Methods of estimating marine mammal diets: a

641 review of validation experiments and sources of bias and uncertainty. Mar.

642 Mamm. Sci. 29(4): 719-754. doi: 10.1111/j.1748-7692.2012.00604.x 
643 Chambellant, M., Stirling, I., and Ferguson, S.H. 2013. Temporal variation in western

644 Hudson Bay ringed seal Phoca hispida diet in relation to environment. Mar.

645 Ecol. Prog. Ser. 481: 269-287. doi: 10.3354/meps 10134.

646 Citta J.J., Suydam R.S., Quakenbush L.T., Frost K.J., and O’Corry-Crowe G.M. 2013.

647 Dive behavior of eastern Chukchi beluga whales (Delphinapterus leucas), 1998-

648 2008. Arctic, 66: 389-406. doi: 10.14430/arctic4326

649 Crawford J.A., Quakenbush L.T., and Citta J.J. 2015. A comparison of ringed and

650

651

bearded seal diet, condition and productivity between historical (1975-1984) and recent (2003-2012) periods in the Alaskan Bering and Chukchi seas. Prog.

652

Oceanogr. 136:133-150. doi:10.1016/j.pocean.2015.05.011.

653 Creswell, J.W. 2007. Qualitative inquiry and research design: Choosing among five 654 approaches ( $3^{\text {rd }}$ ed.). Sage Publications, Los Angeles, C.A.

655 Creswell, J. W. 2009. Research design: Qualitative, quantitative, and mixed methods

656 approaches. 3rd ed. Sage Publications, Los Angeles, C.A.

657 Davis, A., and Wagner, J.R. 2003. Who knows? On the importance of identifying

658 "expert" when researching local ecological knowledge. Hum. Ecol. 31(3): 463-

659 489. doi: 10.1023/A:1025075923297.

660 Davoren, G.K., and Montevecchi, W.A. 2003. Signals from seabirds indicate changing

661 biology of capelin stocks. Mar. Ecol. Prog. Ser. 258: 253-261. doi:

$662 \quad \underline{10.3354 / \mathrm{meps} 258253 .}$

663 Derocher, A.E., Lunn, N.J., and Stirling, I. 2004. Polar bears in a warming climate.

664 Integr. Comp. Biol. 44: 163-176. doi: 10.1093/icb/44.2.163.

665 Doan K.H., and Douglas C.W.. 1953. Beluga of the Churchill region of Hudson Bay. Bull. 
Fish. Res. Board Canada 98: 1-27.

667 Doidge, W., Adams, W., and Burgy, C. 2002. Traditional ecological knowledge of beluga 668 vagues.dfo-mpo.gc.ca [accessed 6 October 2015].

671 Fetters, M.D., Curry, L.A., and Creswell, J.W. 2013. Achieving integration in mixed methods designs - Principles and practices. Health Serv. Res. 48(6): 2134-2156. doi: $10.1111 / 1475-6773.12117$.

674

675

676

677 whales in Nunavik: Interviews from Puvirnituq, Umiujaq and Kuujjuaraapik. Makivik Corporation, Kuujjuaq. pp. 20-20. Available from http://waves-

Gadamus, L., and Raymond-Yakoubian, J. 2015. Qualitative participatory mapping of seal and walrus harvest and habitat areas: Documenting Indigenous knowledge, perserving local values, and discouraging map misuse. Int. J. Appl. Geospatial Res. 6(1): 76-93. doi: 10.4018/ijagr.2015010105.

Gagnon, C.A., and Berteaux, D. 2009. Integrating traditional ecological knowledge and ecological science: A question of scale. Ecol. Soc. 14(2): 19[online]. URL: http://www.ecologyandsociety.org/ vol14/iss2/art19/.

Gaston, A.J., Woo, K., and Hipfner, J.M. 2003. Trends in forage fish populations in northern Hudson Bay since 1981, as determined from the diet of nestling thickbilled murres, Uria lomvia. Arctic, 56(3): 227-233. doi: 10.14430/arctic618.

Gavrilchuk, K., and Lesage, V. 2014. Large-scale marine development projects infrastructure (mineral, oil and gas) proposed for Canada's North. Can. Tech. Rep. Fish. Aquat. Sci. 3069: pp. viii + 84. Available from http://publications.gc.ca/collections/collection_2014/mpo-dfo/Fs97-6-3069eng.pdf [accessed 6 October 2015]. 
689 Glémet, H., Blier, P., and Bernatchez, L. 1998. Geographical extent of Arctic char

$690 \quad$ (Salvelinus alpinus) mtDNA introgression in brook char populations $(S$.

691 fontinalis) from eastern Québec, Canada. Mol. Ecol. 7: 1655-1662. doi:

$692 \quad \underline{10.1046 / j .1365-294 x .1998 .00494 . x}$.

693 Goetz, K.T., Montgomery, R.A., Ver Hoef, J.M., Hobbs, R.C., and Johnson, D.S. 2012.

694 Identifying essential summer habitat of the endangered beluga whale

695 Delphinapterus leucas in Cook Inlet, Alaska. Endanger. Species Res.16: 135-

696 147. doi: $10.3354 /$ esr00394.

697 Hammar, J., Dempson, J.B., and Verspoor, E. 1991. Natural hybridization between Arctic 698 char (SalveIinus alpinus) and brook trout (S. fontinalis): Evidence from northern 699 Labrador. Can. J. Fish. Aquat. Sci. 48(8): 1437-1445. doi: 10.1139/f91-171.

700 Hammill, M.O. 2013. Effects of climate warming on Arctic marine mammals in Hudson 701

702 Bay: Living on the edge? In Responses of Arctic Marine Ecosystems to Climate Change. Edited by F.J. Mueter, D.M.S. Dickson, H.P. Huntington, J.R. Irvine, E.A. Logerwell. S.A. MacLean, L.T. Quakenbush, and C. Rosa. Alaska Sea Grant, University of Alaska Fairbanks. pp. 021-038. doi: $\underline{10.4027 / \text { ramecc. } 2013.02 .}$.

706 Harington, C.R. 2008. The evolution of Arctic marine mammals. Ecol. Appl. 18(2)Supplement: S23-S40. doi: doi:10.1890/06-0624.1.

708 Hauser D., Laidre K., Parker-Stetter S., Horne J., Suydam R., and Richard P. 2015.

709 Regional diving behavior of Pacific Arctic beluga whales Delphinapterus leucas

710 and possible associations with prey. Mar. Ecol. Prog. Ser. 541:245-264.

711 doi:10.3354/meps 11530 . 
712 Hauser D.D.W, Laidre K.L., Suydam R.S., and Richard P.R. 2014. Population-specific

713

714

715

716

717

718

719

720

721

722

723

724

725

726

727

728

729

730

731

732

733

734

home ranges and migration timing of Pacific Arctic beluga whales (Delphinapterus leucas). Polar Biol. 37:1171-1183. doi:10.1007/s00300-0141510-1.

Heide-Jørgensen, M.P., and Teilmann, J. 1994. Growth, reproduction, age structure, and feeding habits of white whales (Delphinapterus leucas) in West Greenland waters. Meddelelser om Grфnland, Biosci. 39: 195-212.

Higdon, J.W., and Ferguson, S.H. 2009. Loss of Arctic sea ice causing punctuated change in sightings of killer whales (Orcinus orca) over the past century. Ecol. Appl. 9(5): 1365-1375. doi: 10.1890/07-1941.1.

Hobbs, R.C., Shelden, K.E.W., Rugh, D.J., and Norman, S.A. 2008. 2008 status review and extinction risk assessment of Cook Inlet belugas (Delphinapterus leucas). AFSC Processed Rep. 2008-02, 116 p. Alaska Fish. Sci. Cent., NOAA, Natl. Mar. Fish. Serv., 7600 Sand Point Way NE, Seattle WA 98115.

Huntington, H.P. 1998. Observations on the utility of the semi-directive interview for documenting traditional ecological knowledge. Arctic, 51(3): 237-242. doi: http://dx.doi.org/10.14430/arctic1065.

Huntington, H.P. 2000. Traditional knowledge of the ecology of belugas, Delphinapterus leucas, in Cook Inlet, Alaska. Mar. Fish. Rev. 62(3): 134-140.

Huntington, H.P., and the Communities of Buckland, Elim, Koyuk, Point Lay, and Shaktoolik, E. 1999. Traditional knowledge of the ecology of beluga whales (Delphinapterus leucas) in the eastern Chukchi and northern Bering Seas, Alaska. Arctic, 52(1): 49-61. doi: 10.14430/arctic909. 
735 Inuit Tapiriit Kanatami (ITK). 2008. Inuit in Canada: A Statistical Profile. Available from 736 https://www.itk.ca/publication/inuit-statistical-profile [accessed 7 October 2015].

738 Kelley, T.C., Loseto, L.L., Stewart, R.E.A., Yurkowski, M., and Ferguson, S.H. 2010. 739 Importance of eating capelin: Unique dietary habits of Hudson Bay beluga. In A 740 Little Less Arctic: Top Predators in the World's Largest Northern Inland Sea, 741 Hudson Bay. S.H.Ferguson, L.L. Loseto, and M.L. Mallory. Springer Netherlands, Dordrecht. pp. 53-70. doi: 10.1007/978-90-481-9121-5_3

743 Kilabuk, P. 1998. A study of Inuit knowledge of the Southeast Baffin beluga. The 744 Southeast Baffin Beluga Management Committee. pp. 74. Available from

746 Kingsley, M.C.S., Gosselin, S., and Sleno, G.A. 2001. Movements and dive behaviour of belugas in northern Quebec. Arctic, 54(3): 262-275. doi: 10.14430/arctic786.

Kleinenberg S.E., Yablokov A.V., Bel'kovich V.M., and Tarasevich M.N. 1964. Beluga (Delphinapterus leucas): Investigation of the species. Moscow Tra. Nauk SSSR,

751 Koski, W.R., Davis, R.A., and Finley, K.J. 2002. Distribution and abundance of Canadian 752 High Arctic belugas, 1974-1979. NAMMCO Sci. Publ. 4: 87-126. doi:

753 $\underline{10.7557 / 3.2839}$.

754 Krupnik, I. 2009. "The Way We See It Coming”: Building the Legacy of Indigenous 755 Observations in IPY 2007 - 2008. In Smithsonian at the Poles: Contributions to 756 International Polar Year Science. Edited by I. Krupnik, M. Lang, and S.

757 Millereds. Smithsonian Institution Scholarly Press. pp. 129-142 
758 Laidre, K.L., Stirling, I., Lowry, L.F., Wiig, Ø., Heide-Jorgensen, M.P., and Ferguson,

759

760

761

762

763

764

765

766

767

768

769

770

771

772

773

774 Loseto, L.L., Richard, P., Stern, G.A., Orr, J., and Ferguson, S.H. 2006. Segregation of 775

776

777

778

779

780

S.H. 2008. Quantifying the sensitivity of Arctic marine mammals to climateinduced habitat change. Ecol. Appl. 18(2)Supplement: S97-S125. doi: $\underline{10.1890 / 06-0546.1}$.

Lee, D., Doidge, W., Burgy, C., and Adams, W. 2002. Traditional ecological knowledge in relation to the management of beluga whales in Nunavik Phase I. Interviews at Kangirsuk, Salluit and Inukjuak. Makivik Corporation. Kuujjuaq. Quebec J0M 1C0. pp. 16p + Appendix of 18 maps.

Lemire, M., Kwan, M., Laouan-Sidi A.E., Muckle, G., Pirkle, C., Ayotte, P., and Dewailly, E. 2015. Local country food sources of methylmercury, selenium and omega-3 fatty acids in Nunavik, Northern Quebec. Sci. Total Environ. 509510:248-259. doi:10.1016/j.scitotenv.2014.07.102.

Lewis, A.E., Hammill, M.O., Power, M., Doidge, D.W., and Lesage, V. 2009. Movement and aggregation of eastern Hudson Bay beluga whales (Delphinapterus leucas): A comparison of patterns found through satellite telemetry and Nunavik traditional ecological knowledge. Arctic, 62(1): 13-24. doi: 10.14430/arctic109. Beaufort Sea beluga whales during the open-water season. Can. J. Zool. 84(12): 1743-1751. doi:10.1139/Z06-160.

Loseto, L.L., Stern, G.A., Connelly, T.L., Deibel, D., Gemmill, B., Prokopowicz, A., Fortier, L., and Ferguson, S.H. 2009. Summer diet of beluga whales inferred by fatty acid analysis of the eastern Beaufort Sea food web. J. Exp. Mar. Bio. Ecol. 374(1): 12-18. doi: DOI: 10.1016/j.jembe.2009.03.015. 
781 Loseto, L.L.L., Stern, G.A.A., Deibel, D., Connelly, T.L.L., Prokopowicz, A., Lean,

782 D.R.S., Fortier, L., and Ferguson, S.H. 2007. Linking mercury exposure to

783 habitat and feeding behaviour in Beaufort Sea beluga whales. J. Mar. Syst. 74:

784 1012-1024. doi: 10.1016/j.jmarsys.2007.10.004.

785 Loseto, L.L.L., Stern, G.A.A., and Ferguson, S.H. 2008. Size and biomagnification: How

786 habitat selection explains beluga mercury levels. Environ. Sci. Technol. 42:

787 3982-3988. doi: 10.1021/es7024388.

788 Marcoux, M., McMeans, B.C., Fisk, A.T., and Ferguson, S.H. 2012. Composition and

789 temporal variation in the diet of beluga whales, derived from stable isotopes.

790 Mar. Ecol. Prog. Ser. 471: 283-291. doi: 10.3354/meps10029.

791 Matthews, C.J.D., and Ferguson, S.H. 2015. Weaning age variation in beluga whales

792

(Delphinapterus leucas). J. of Mammal. 96(2): 425-437. doi:

793 10.1093/jmammal/gyv046.

794 McDonald, M., Arragutainaq, L., and Novalinga, Z. (eds.). 1997. Voices from the bay:

795 Traditional ecological knowledge of Inuit and Cree in the Hudson Bay

796 bioregion. Canadian Arctic Resource Committee, Environmental Committee of

797 Municipality of Sanikiluaq, Ottawa/Sanikiluaq. pp. 98.

798 McLeod, B.A., Furgal, C.M., Doidge, W., and Hammill, M.O. 2009. A field guide to prey 799 of beluga (Delphinapterus leucas) of the Canadian Arctic. Makivik Corporation. $800 \quad$ Kuujjuaq, Quebec J0M 1 C0.

801 Morin, R., Dodson, J., and Power, G. 1980. Estuarine fish communities of the eastern 802 James-Hudson Bay coast. Environ. Biol. Fishes 5(2): 135-141. doi:

$803 \quad 10.1007 /$ bf02391620. 
804 Mosnier, A., Lesage, V., Gosselin, J.F., Lemieux Lefebvre, S., Hammill, M.O., and 805 Doniol-Valcroze, T. 2010. Information relevant to the documentation of habitat 806 807 use by St. Lawrence beluga (Delphinapterus leucas), and quantification of 808 809 habitat quality. DFO Can. Sci. Advis. Sec., Res. Doc. 2009/098. pp. iv +35 .

Mymrin, N.I., The communities of Novoe Chaplino, Sireniki, Uelen, and Yankrakinnot,

Quakenbush L.T., Suydam R.S., Bryan A.L., Lowry L.F., Frost K.J., and Mahoney B.A. 813 2015. Diet of beluga whales, Delphinapterus leucas, in Alaska from stomach contents, March-November. Mar. Fish. Rev. 77: 70-84.

815 doi:10.7755/MFR.77.1.7.

816 Richard, P.R., Heide-Jørgensen, M.P., Orr, J.R., Dietz, R., and Smith, T.G. $2001 a$. Summer and autumn movements and habitat use by belugas in the Canadian High Arctic and adjacent areas. Arctic, 54(3): 207-222. doi: 10.14430/arctic782.

819 Richard, P.R., Heide-Jørgensen, M.P., and St. Aubin, D. 1998. Fall movements of 820 belugas (Delphinapterus leucas) with satellite-linked transmitters in Lancaster

823 Richard, P.R., Martin, A.R., and Orr, J.R. 2001b. Summer and autumn movements of 824 belugas of the Eastern Beaufort Sea stock. Arctic, 54(3): 223-236. doi:

825 10.14430/arctic 783 . 
826 Robards, M.D., and Piatt, J.F. 1999. Biology of the genus Ammodytes, the sand lances. In

827

828

829

830

831

832

833

834

835

836

837

838

839

840

841

842

843

844

845

846

847

Sand lance: A review of biology and predator relations and annotated bibliography. Edited by M.D. Robards, M.F. Willson, R.H. Armstrong, and J.F. Piatt. 1999. Res. Pap. PNW-RP-521. Portland, OR: U.S. Department of Agriculture, Forest Service, Pacific Northwest Research Station. pp. 1-16.

Scott, W.B., and Crossman, E.J. 1973. Freshwater fishes of Canada. Bull. Fish. Res. Board Can., Ottawa, Canada.

Seaman GA, Lowry LF, Frost KJ. 1982. Foods of belukha whales (Delphinapterus leucas) in western Alaska. Cetology, 44: 1-19.

Sergeant, D.E. 1962. The Biology and Hunting of Beluga or White Whales in the Canadin Arctic. Fish. Res. Board Can. Arctic Unit, Montreal, Que. Circ. 8: pp. 13. Available from http://publications.gc.ca/site/eng/447887/publication.html [accessed 7 October 2015].

Sergeant, D.E. 1973. Biology of white whales (Delphinapterus leucas) in western Hudson Bay. J. Fish. Res. Board Canada 30(8): 1065-1090. doi: 10.1139/f73178.

Simpson, L.R. 2004. Anticolonial Strategies for the Recovery and of Indigenous Maintenance Knowledge. Am. Indian Q. 28(3\&4): 373-384. doi: 10.1353/aiq.2004.0107.

Smith, T.G., and Stirling, I. 1975. The breeding habitat of the ringed seal (Phoca hispida). The birth lair and associated structures. Can. J. Zool. 53(9): 1297-1305. doi: 10.1139/z75-155. 
848 St Aubin, D.J., Smith, T.G., and Geraci, J.R. 1990. Seasonal epidermal molt in beluga 849 whales, Delphinapterus leucas. Can. J. Zool. 68: 359-367. doi: 10.1139/z90-051.

850 Stewart, D.B., and Lockhart, W.L. 2005. An overview of the Hudson Bay marine 851 ecosystem. Canadian Technical Report of Fisheries and Aquatic Sciences no. 852 2586. pp. vi +487 .

853 Stroeve, J.C., Serreze, M.C., Holland, M.M., Kay, J.E., Malanik, J., and Barrett, A.P. 854 2012. The Arctic's rapidly shrinking sea ice cover: A research synthesis. Clim. 855 Change 110: 1005-1027. doi: 10.1007/s10584-011-0101-1.

856 Suydam, R.S., Lowry, L.F., Frost, K.J., O'Corry-Crowe, G.M., and Pikok, D.Jr. 2001. 857 Satellite tracking of eastern Chukchi Sea beluga whales into the Arctic Ocean. Arctic, 54(3): 237-243. doi: 10.14430/arctic784.

859 Thiemann, G.W., Iverson, S.J., and Stirling, I. 2008. Variation in blubber fatty acid 860 composition among marine mammals in the Canadian Arctic. Mar. Mammal Sci. 861 24(1): 91-111. doi: 10.1111/j.1748-7692.2007.00165.x.

862 Tomilin AG. 1967. Mammals of the U.S.S.R. and adjacent countries. Cetacea, 9: 666863696.

864 Turgeon, J., Duchesne, P., Colbeck, G.J., Postma, L.D., and Hammill, M.O. 2011.

865 Spatiotemporal segregation among summer stocks of beluga (Delphinapterus 866 leucas) despite nuclear gene flow: implication for the endangered belugas in 867 eastern Hudson Bay (Canada). Conserv. Genet. 13(2): 419-433. doi:

$868 \quad 10.1007 / \mathrm{s} 10592-011-0294-x$. 
869 Vladykov, V.D. 1946. Études sur les mammifères aquatiques IV: Nourriture du marsouin 870 blanc ou béluga (Delphinapterus leucas) du fleuve St-Laurent. Département des 871 Pêcheries, Québec, QC.

872 Watts, P.D., and Draper, B.A. 1986. Note on the behavior of beluga whales feeding on 873 capelin. Arct. Alp. Res. 18(4): 439-439. doi: 10.2307/1551093

874 Worton, B.J. 1989. Kernel methods for estimating the utlization distribution in home875 range studies. Ecology, 70(1): 164-168. doi: 10.2307/1938423.

876 
877 Table 1: Summary statistics for participants in beluga interviews conducted in

878 Kangiqsualujjuaq, Quaqtaq, Ivujvik, and Kuujjuaraapik*.

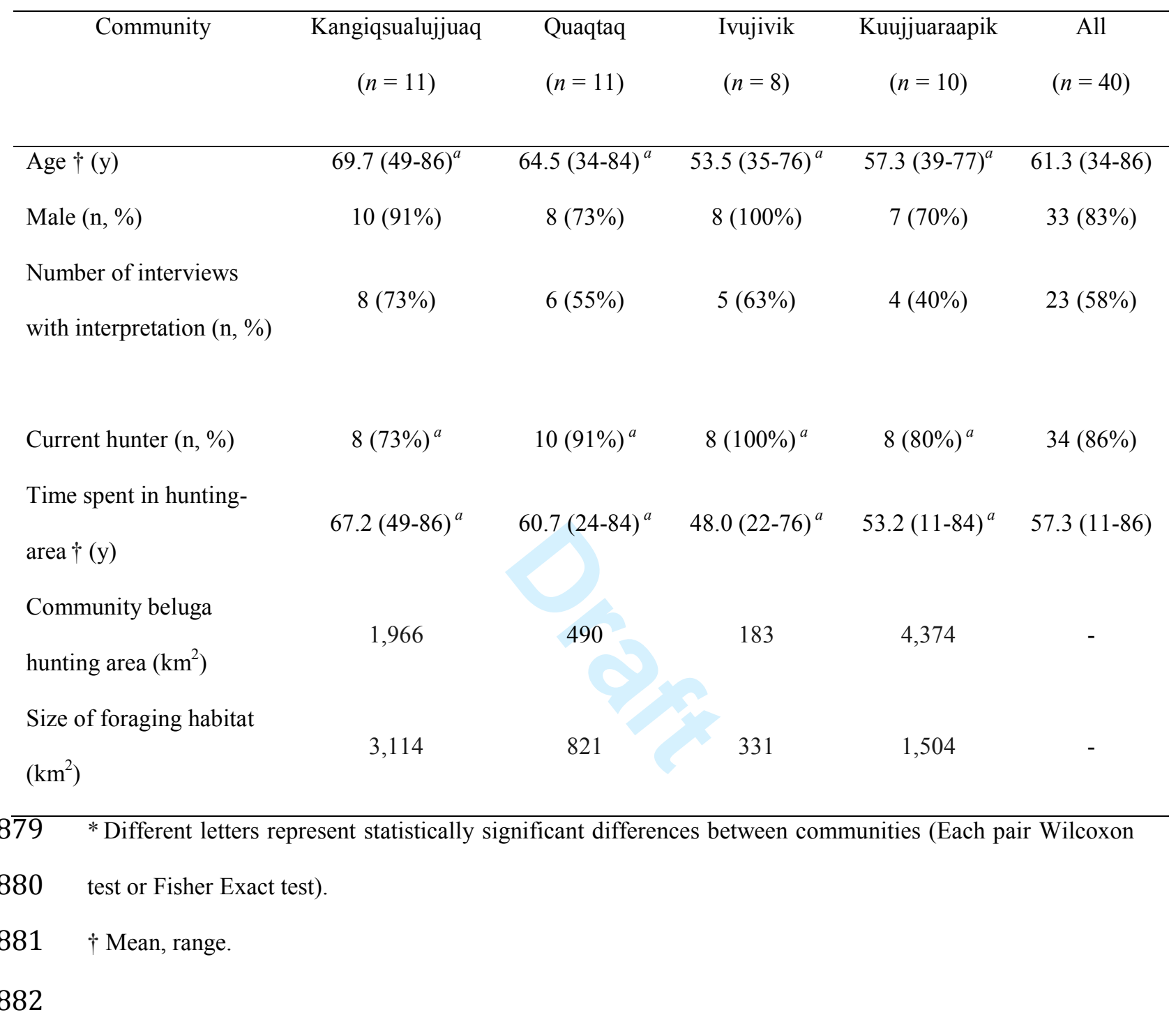


883 Table 2: Percentages of participants that identified prey species to the family taxonomic 884 level during initial interviews and later validated. All prey identified to species are listed 885 by family, with the exception of cod. *

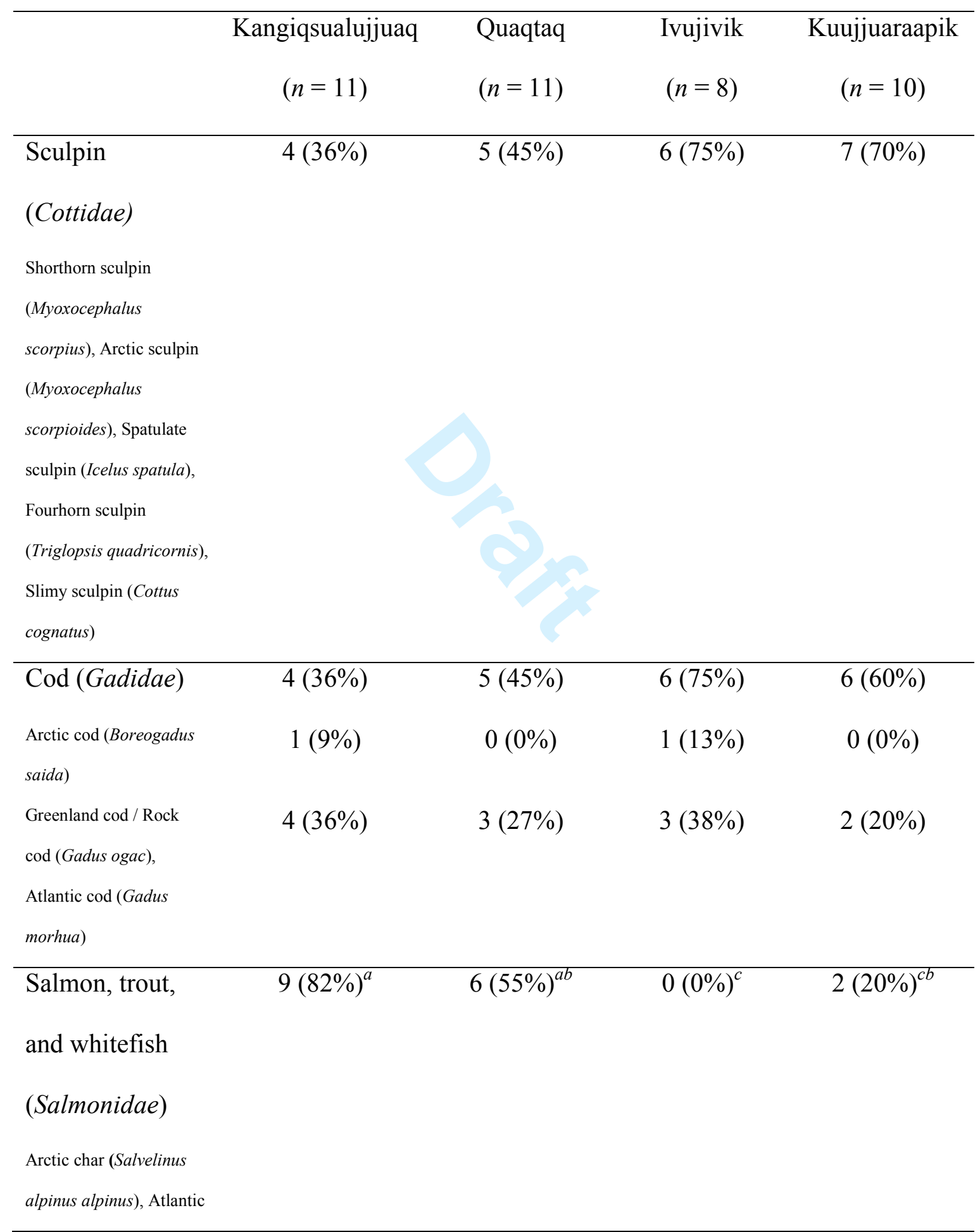




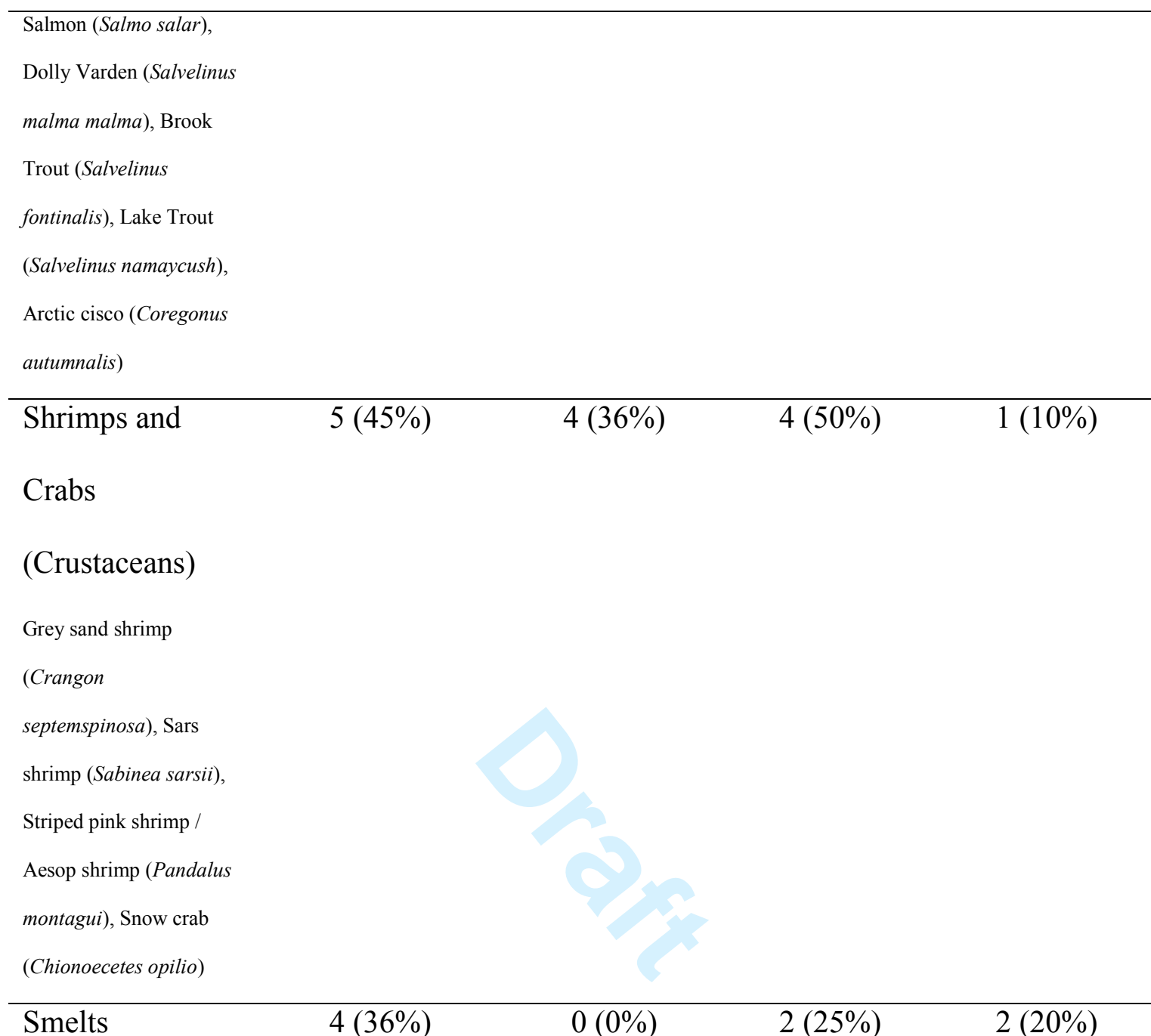

\begin{tabular}{lllll}
\hline Smelts & $4(36 \%)$ & $0(0 \%)$ & $2(25 \%)$ & $2(20 \%)$
\end{tabular}

\section{(Osmeridae)}

Capelin (Mallotus

villosus)

\begin{tabular}{lllll}
\hline Sandlance & $0(0 \%)$ & $3(27 \%)$ & $0(0 \%)$ & $0(0 \%)$ \\
$($ Ammodytidae $)$ & & &
\end{tabular}

\begin{tabular}{lllll}
\hline Herring & $2(18 \%)$ & $0(0 \%)$ & $0(0 \%)$ & $0(0 \%)$
\end{tabular}

\section{(Clupeidae)}

(Clupea harengus

harengus) 
888 
889 Table 3: Percentage of participants who discussed foraging habitat, and particular habitat 890 types (as a proportion of the respondent group) (n, \%). *

$$
\begin{array}{ccccc}
\text { Kangiqsualujjuaq } & \text { Quaqtaq } & \text { Ivujivik } & \text { Kuujjuaraapik } & \text { All } \\
(n=11) & (n=11) & (n=8) & (n=10) & \text { participants } \\
& & & & (n=40)
\end{array}
$$

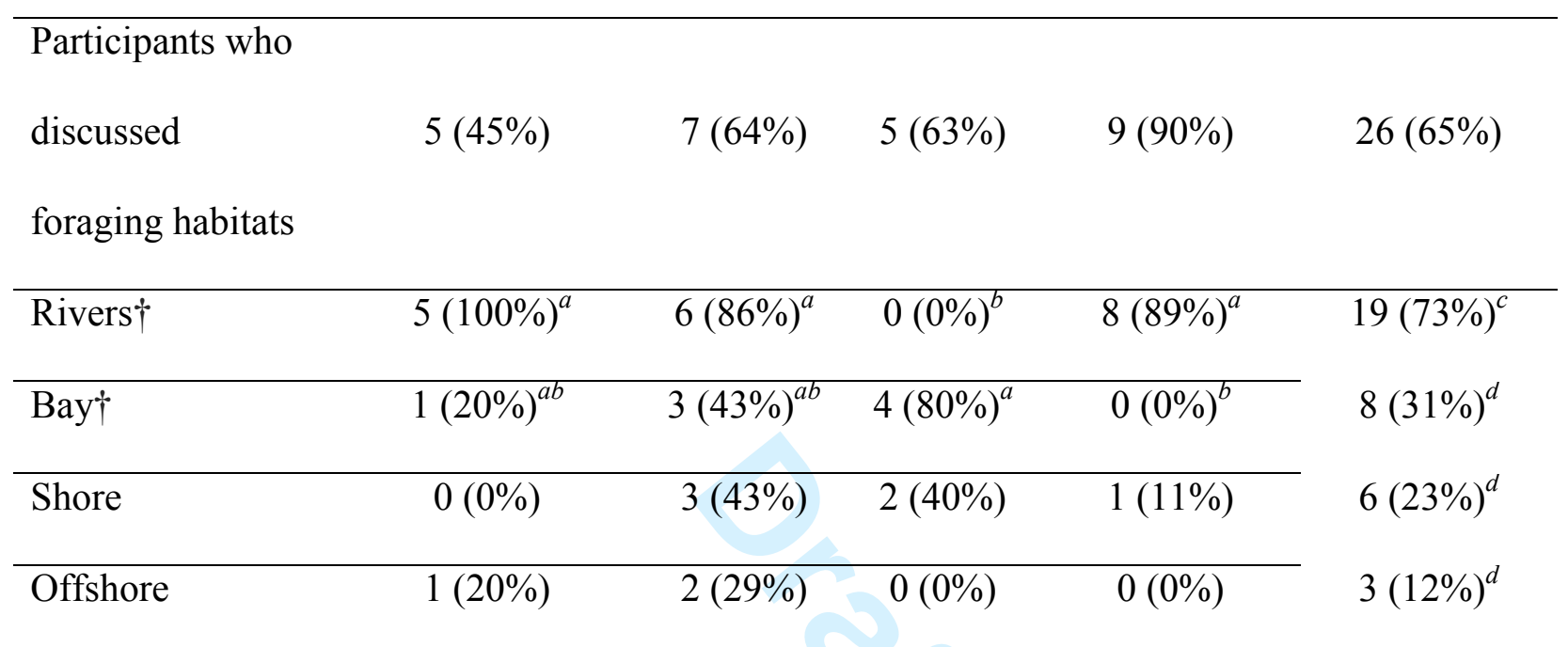

$891 *$ Different letters represent statistically significant differences between habitats or between communities (Fisher's Exact test)

$892 \dagger$ Indicates those habitat types for which there is statistical difference

893

894 
895 Table 4: Observations of Stomach contents (n, \%).

\begin{tabular}{|c|c|c|c|c|}
\hline & $\begin{array}{l}\text { Kangiqsualujjuaq } \\
(n=11)\end{array}$ & $\begin{array}{l}\text { Quaqtaq } \\
(n=11)\end{array}$ & $\begin{array}{l}\text { Ivujivik } \\
(n=8)\end{array}$ & $\begin{array}{c}\text { Kuujjuaraapik } \\
(n=10)\end{array}$ \\
\hline $\begin{array}{l}\text { Participants } \\
\text { who look at } \\
\text { stomach } \\
\text { contents (\%) }\end{array}$ & $9(82 \%)$ & $5(45 \%)$ & $6(75 \%)$ & $9(90 \%)$ \\
\hline $\begin{array}{l}\text { Quantity of } \\
\text { stomach }\end{array}$ & $\begin{array}{c}\text { Often empty, } \\
\text { Spring - can have }\end{array}$ & $\begin{array}{c}\text { Spring - fairly } \\
\text { full }\end{array}$ & $\begin{array}{c}\text { Spring - quite } \\
\text { full }\end{array}$ & $\begin{array}{l}\text { Summer - } \\
\text { 1/4- 1/2 full, }\end{array}$ \\
\hline contents & $\begin{array}{l}\text { some contents } \\
\text { Fall - quite } \\
\text { empty, }\end{array}$ & $\begin{array}{l}\text { Fall - quite } \\
\text { empty }\end{array}$ & $\begin{array}{l}\text { Fall - empty } \\
\text { (though more } \\
\text { variable) }\end{array}$ & $\begin{array}{c}\text { though can be } \\
\text { empty }\end{array}$ \\
\hline
\end{tabular}

896

897 
898 Table 5: Participants' observations of changes in blubber thickness at different times of 899 the year.

\begin{tabular}{|c|c|c|c|c|c|}
\hline & $\begin{array}{l}\text { Time of } \\
\text { the Year }\end{array}$ & $\begin{array}{l}\text { Estimated } \\
\text { Blubber } \\
\text { Thickness } \\
\text { (cm) }\end{array}$ & $\begin{array}{l}\text { Time of } \\
\text { the Year }\end{array}$ & $\begin{array}{l}\text { Estimated } \\
\text { Blubber } \\
\text { Thickness } \\
\text { (cm) }\end{array}$ & Notes \\
\hline Kangiqsualujjuaq & & & & & $\begin{array}{l}\text { Describe a change } \\
\text { in blubber } \\
\text { thickness between } \\
\text { seasons but not } \\
\text { reflected as a } \\
\text { measureable } \\
\text { difference }\end{array}$ \\
\hline Quaqtaq & $\begin{array}{l}\text { Spring } \\
\text { migration } \\
\text { (end of } \\
\text { April - } \\
\text { mid July) }\end{array}$ & 12 & $\begin{array}{c}\text { Fall } \\
\text { migration } \\
\text { (beginning } \\
\text { of Sept- } \\
\text { Dec) }\end{array}$ & 5 & $\begin{array}{l}\text { Based on } \\
\text { measurements } \\
\text { around the back } \\
\text { of the neck }\end{array}$ \\
\hline Ivujivik & $\begin{array}{c}\text { Spring } \\
\text { migration } \\
\text { (end of } \\
\text { May - } \\
\text { mid July) }\end{array}$ & 7 & $\begin{array}{c}\text { Fall } \\
\text { migration } \\
(\mathrm{Oct}- \\
\text { Dec) }\end{array}$ & $1-4$ & \\
\hline
\end{tabular}




\begin{tabular}{|c|c|c|c|}
\hline Kuujjuaraapik & $\begin{array}{l}\text { Arrival } \\
\text { (June) }\end{array}$ & $7.5-10$ & $\begin{array}{l}\text { Departure } \\
\text { (September }\end{array}$ \\
\hline
\end{tabular}

November)

900

901 
902 Table 6: Dominant prey species for beluga populations by latitude and method.

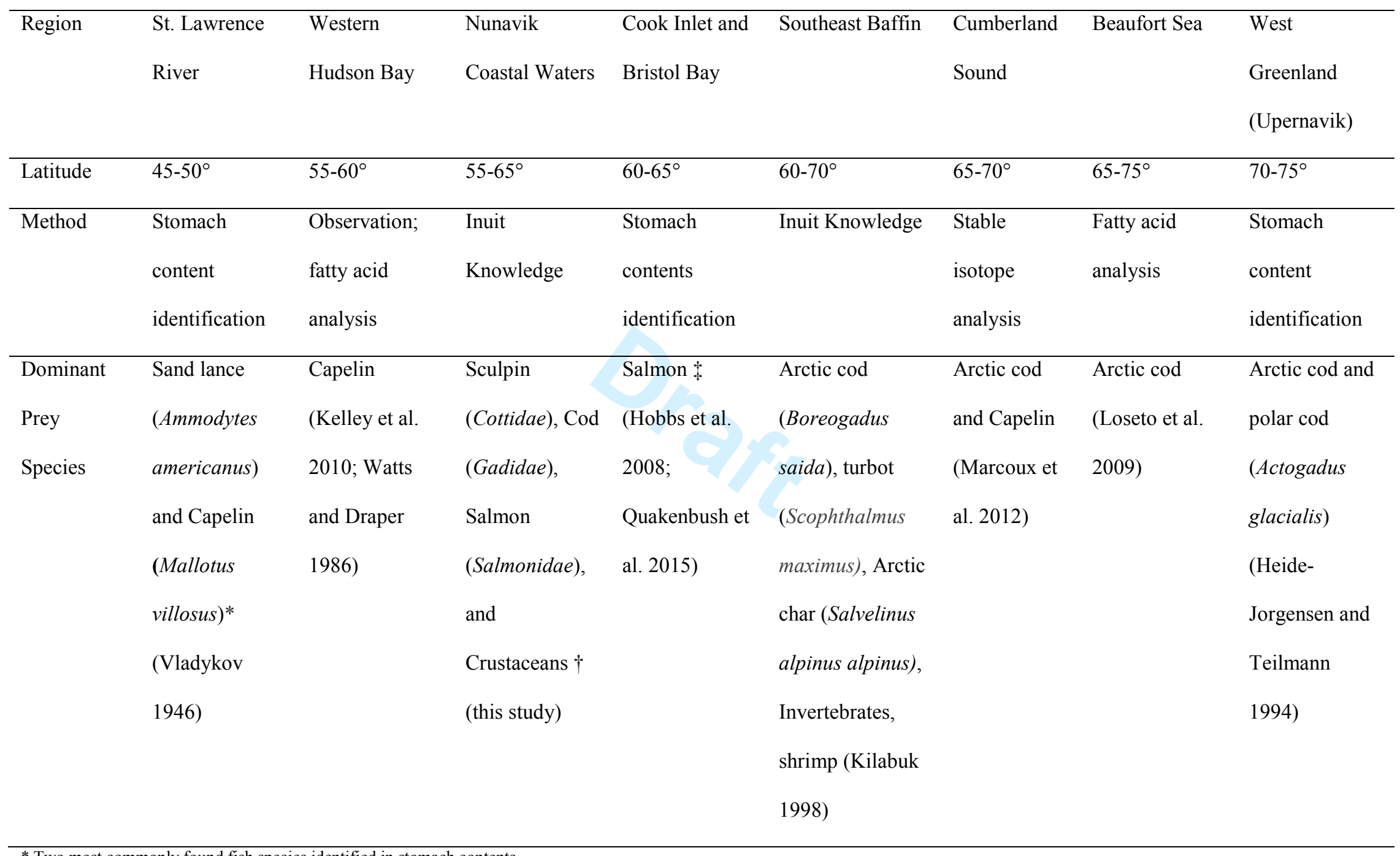

* Two most commonly found fish species identified in stomach contents

$904 \uparrow$ Family groups of species reported most frequently 
906 Figure 1: Map of Nunavik highlighting participating communities - Kuujjuaraapik,

907 Ivujivik, Quaqtaq, and Kangiqsualujjuaq - Killiniq, as well as beluga spring migration

908 (light blue - major migration, dark blue - lesser migration). Note that fall migration is in

909 the reverse direction (adapted from Science of the Total Environment vol. 509-510:

910 Lemire, M., Kwan, M., Laouan-Sidi A.E., Muckle, G., Pirkle, C., Ayotte, P., and

911 Dewailly, E. Local country food sources of methylmercury, selenium and omega-3 fatty

912 acids in Nunavik, Northern Quebec. pp. 248-259, Copyright 2015, with permission from

913 Elsevier).

914 Figure 2: Reporting of beluga prey species by family group from all participants ${ }^{1}$.

$915{ }^{1}$ Different letters represent statistically significant differences between family groups (Fisher's Exact test)

916 Figures 3a-d: Maps showing Nunavimmiut identified feeding areas for a) Kuujjuaraapik,

917 b) Ivujivik, c) Quaqtaq, and d) Kangiqsualujjuaq. Colour intensity represents kernel 918 density estimation of commonality of reported observations. NOTE: THIS MAP IS

919 NOT TO BE REPRODUCED IN ANY WAY, WHOLE OR IN PART. INFORMATION

920 PRESENTED ON THIS MAP ONLY REPRESENTS THAT COLLECTED FROM

921 PARTICIPANTS TO THIS STUDY FROM THE 4 COMMUNITIES INCLUDED. IT

922 DOES NOT REPRESENT ALL NUNAVIMMIUT KNOWLEDGE OF BELUGA 923 FORAGING LOCATIONS FOR THIS REGION.

924 Figure 4: Beluga blubber thickness (cm), showing quantiles (red), in spring and fall as

925 reported by hunters in Quaqtaq and Ivujivik. 


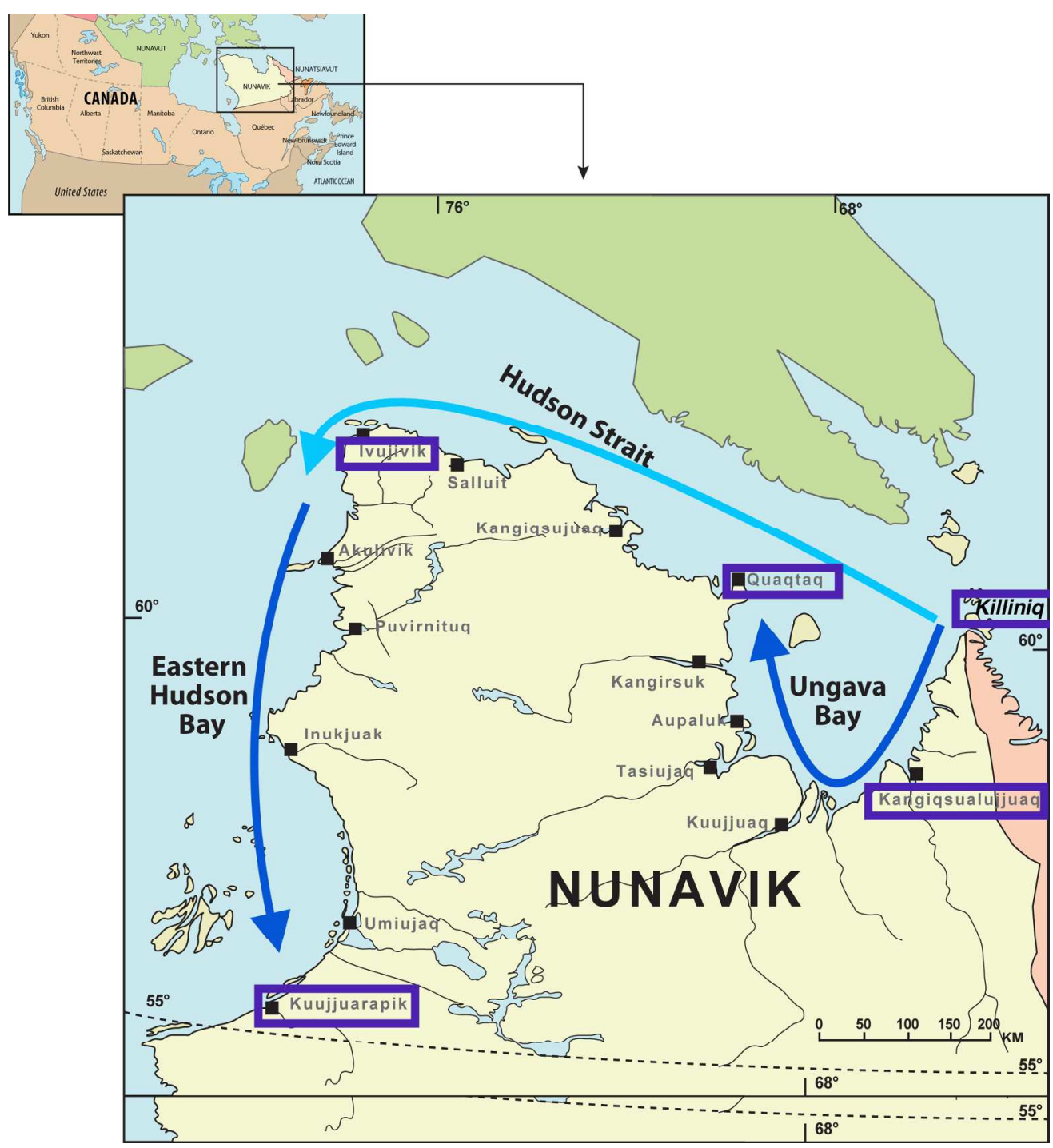

Figure 1: Map of Nunavik highlighting participating communities - Kuujjuaraapik, Ivujivik, Quaqtaq, and Kangiqsualujjuaq - Killiniq, as well as beluga spring migration (light blue - major migration, dark blue lesser migration). Note that fall migration is in the reverse direction (adapted from Science of the Total Environment vol. 509-510: Lemire, M., Kwan, M., Laouan-Sidi A.E., Muckle, G., Pirkle, C., Ayotte, P., and Dewailly, E. Local country food sources of methylmercury, selenium and omega-3 fatty acids in Nunavik, Northern Quebec. pp. 248-259, Copyright 2015, with permission from Elsevier).

\section{$178 \times 194 \mathrm{~mm}(300 \times 300 \mathrm{DPI})$}




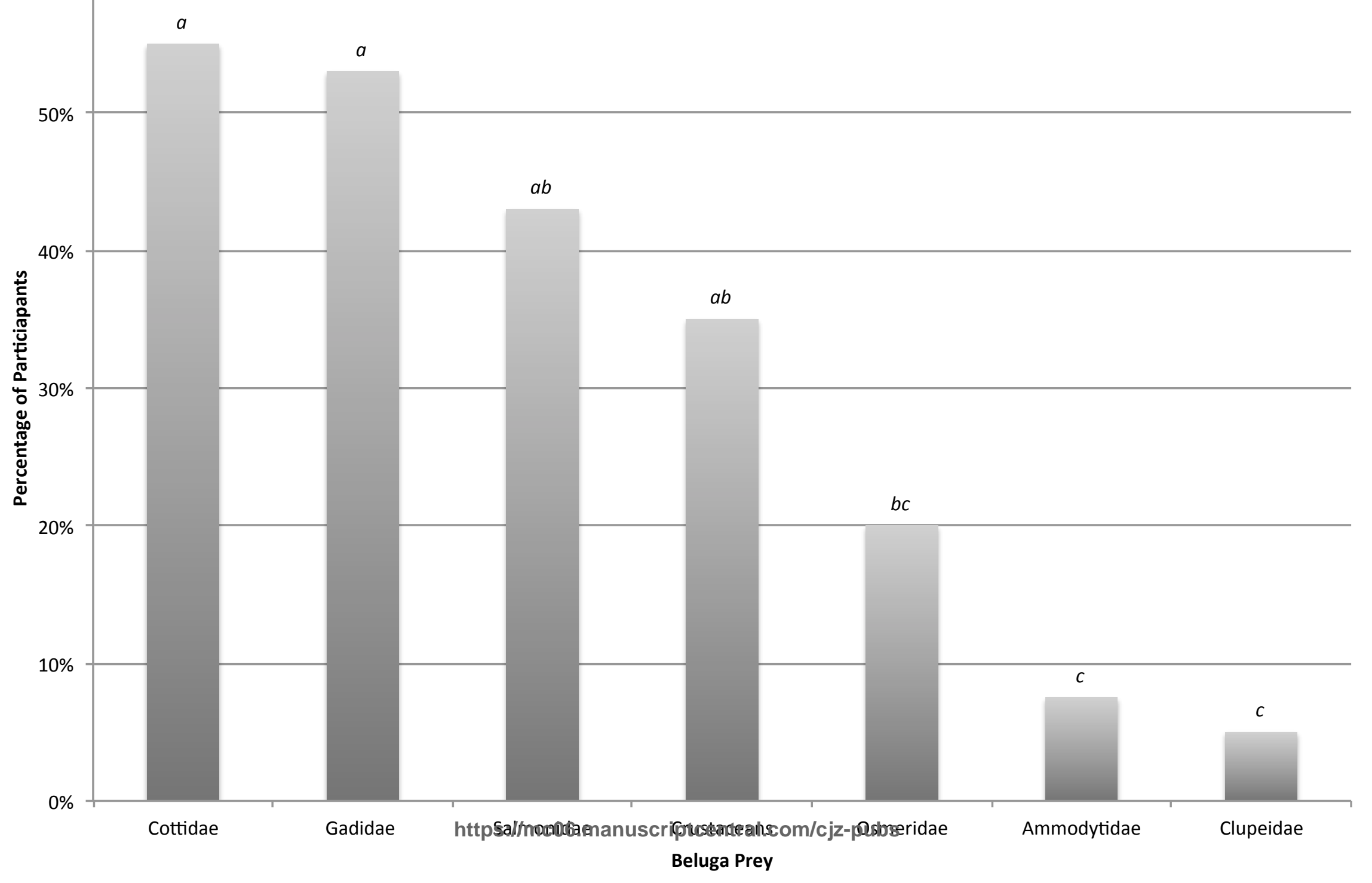

\section{Page653 of 58}

$a$

Canadian Journal of Zoology

$a b$ 
(b)

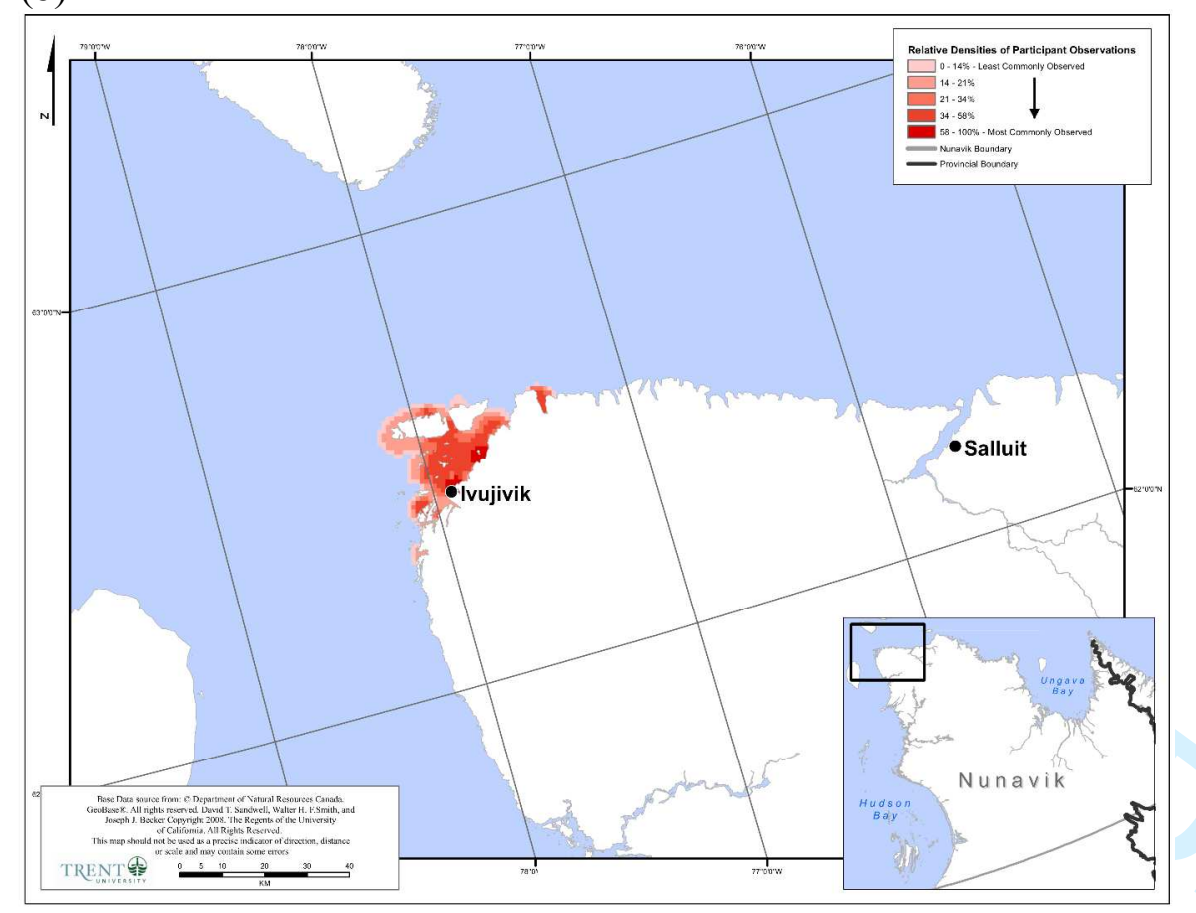

(a)

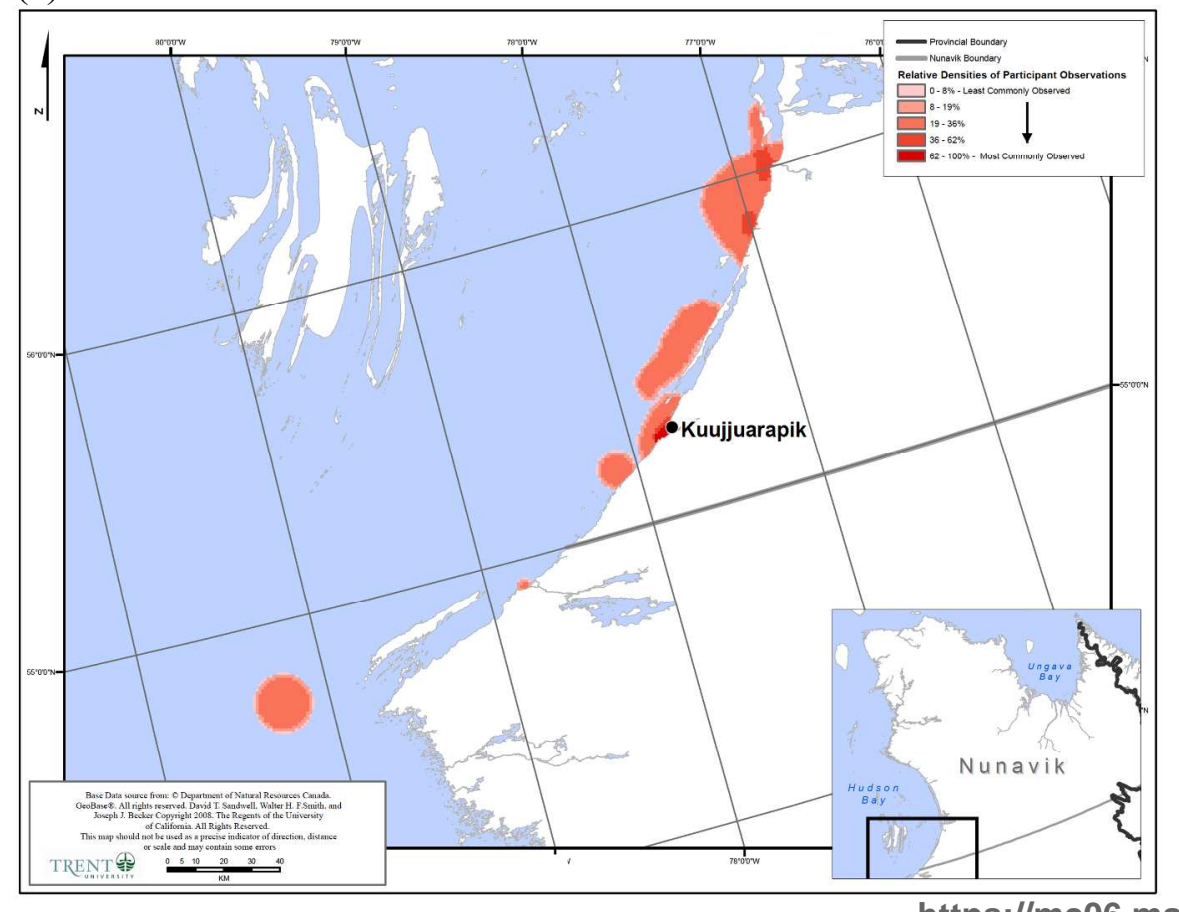

(c)

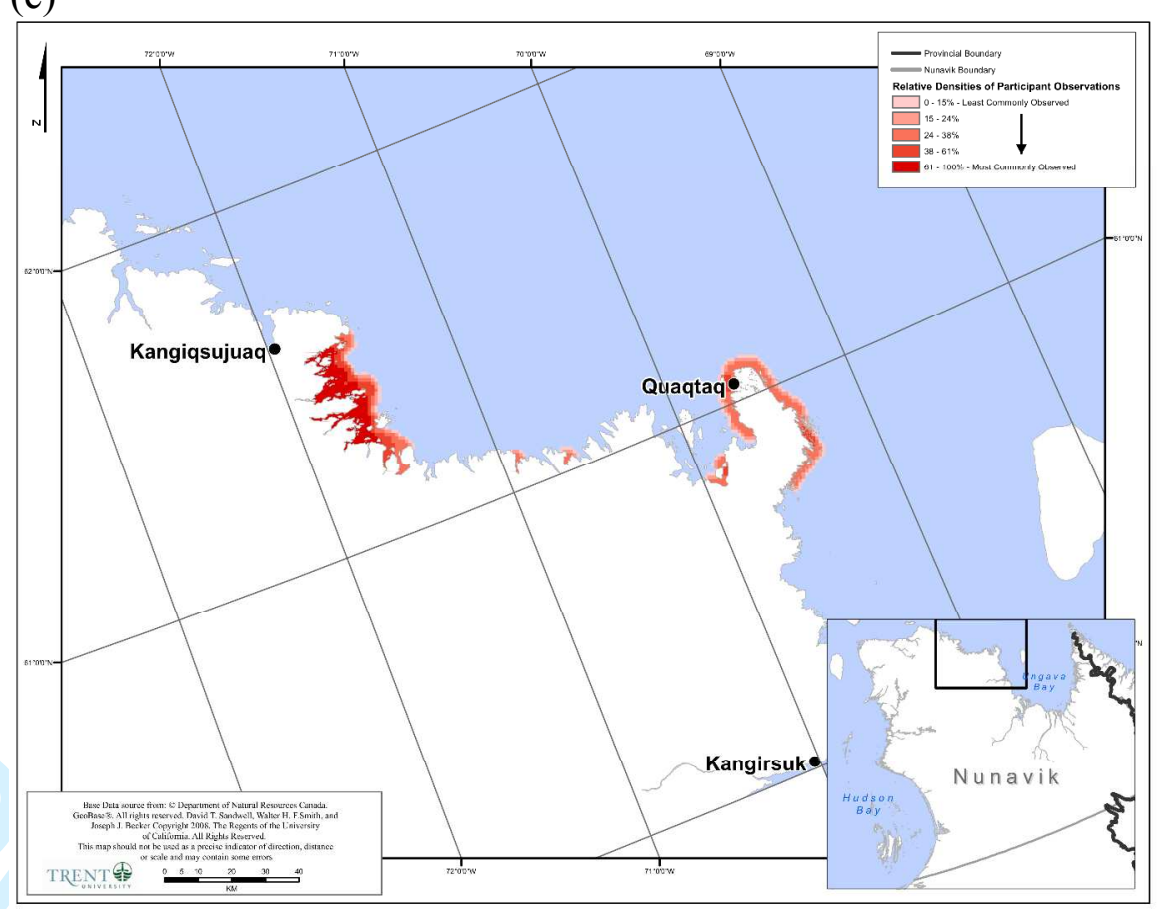

(d)

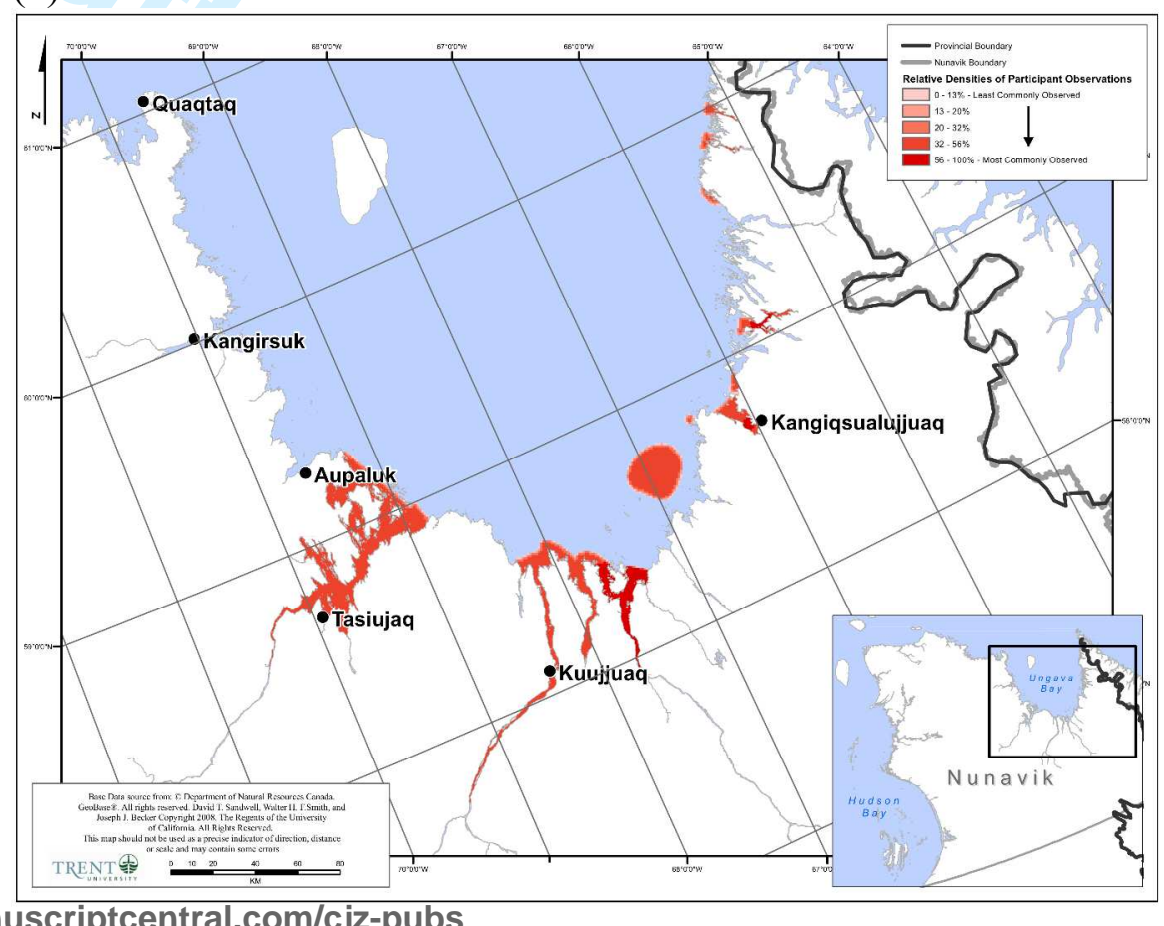




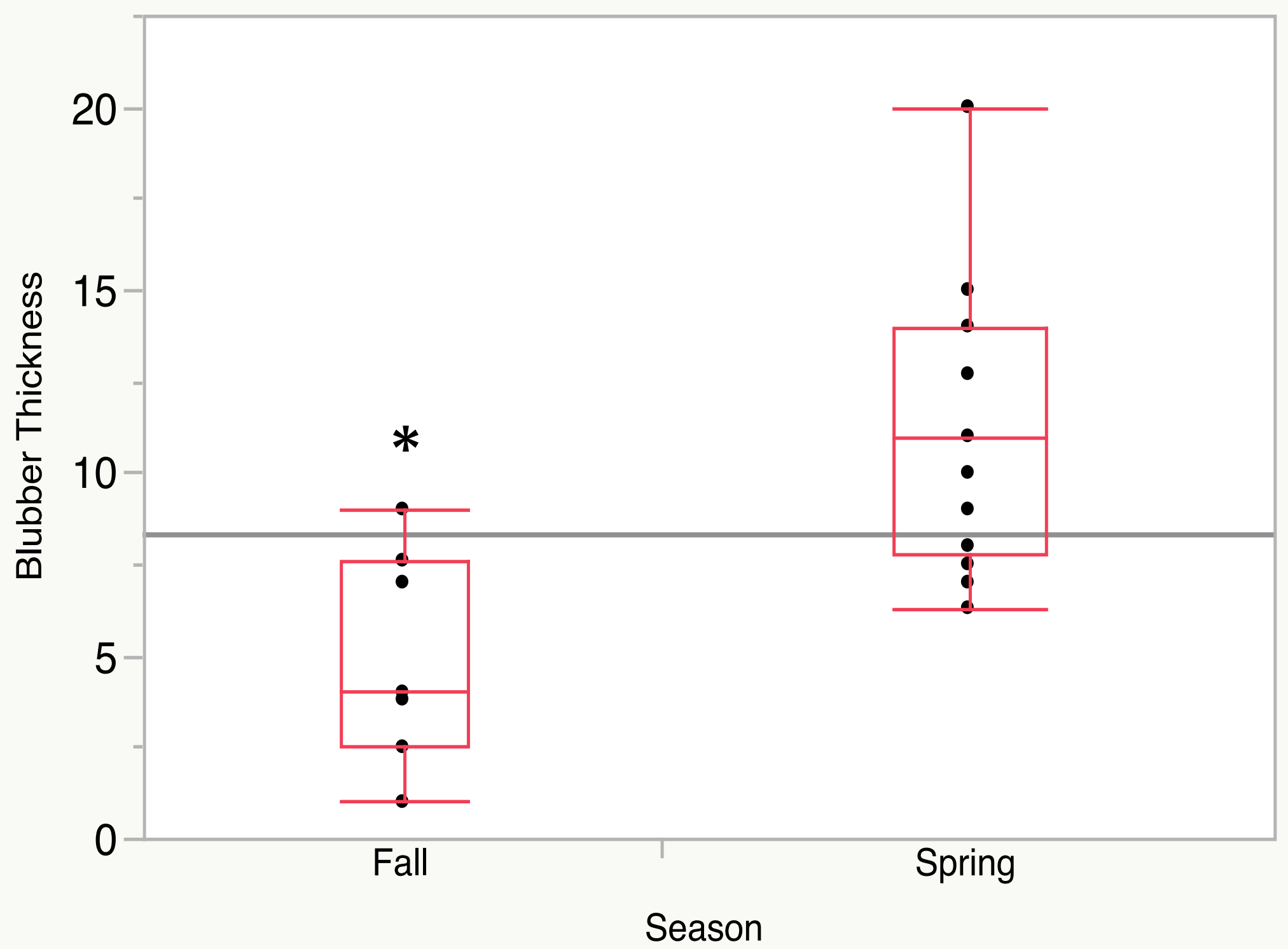

https://mc06.manuscriptcentral.com/cjz-pubs 


\section{Appendix A:}

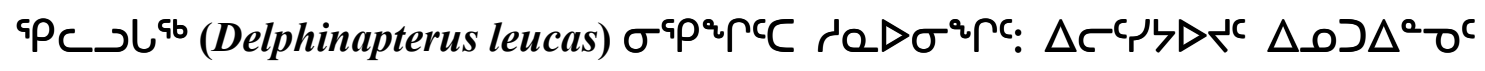

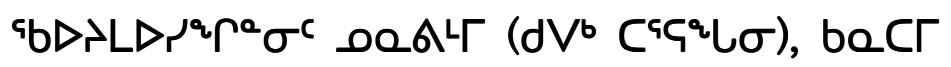
$\dot{P} .>\Omega C^{a}{ }^{a} b \sigma L^{a}$, d.L. $\left.\dot{9} d^{c}, \triangleleft^{L} L\right\lrcorner \wedge .{ }^{a} p \rho$

$D \sigma^{b} b \triangleright C D \sigma^{a} \rho c$

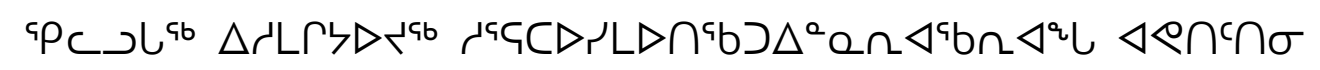

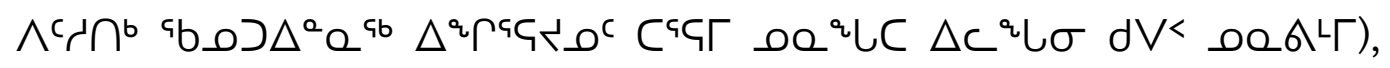

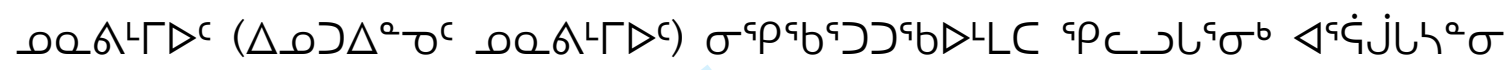
JPL

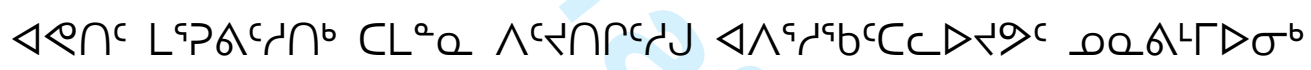

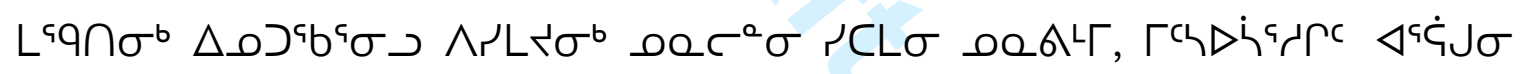

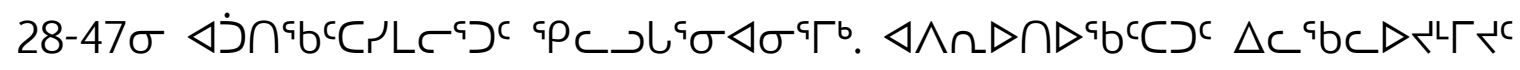

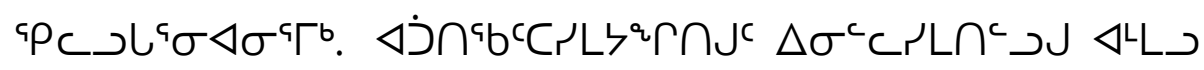

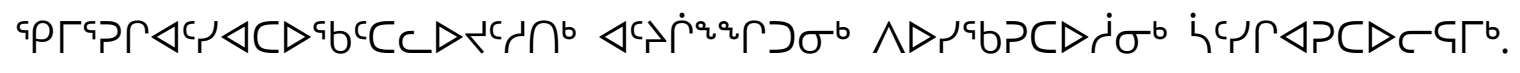

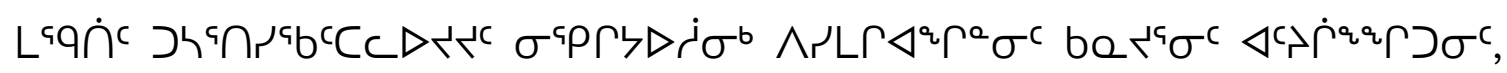
ذأLbb

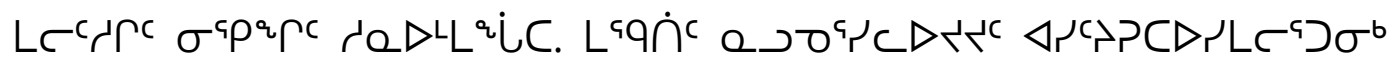

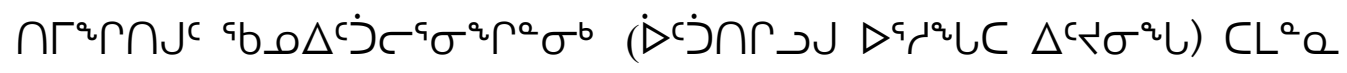
$C D J^{a} \sigma \Gamma \cap J^{c} a^{c} C D \cap^{c} C \sigma^{q} L \rho^{\varsigma \varsigma} p D \sigma^{\varsigma} J^{c} L c^{c} \lambda J$. 
حـد_ח

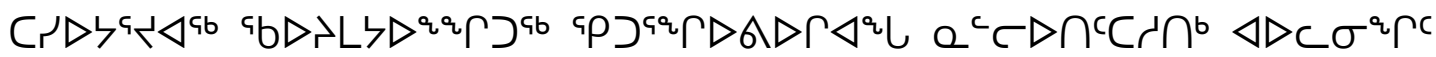

c

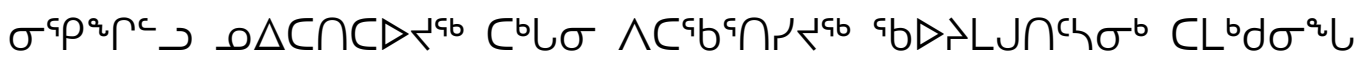

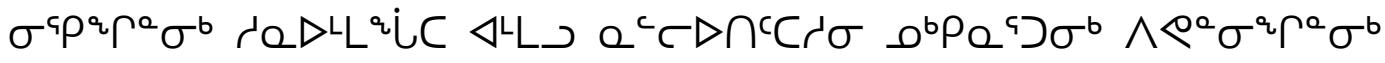

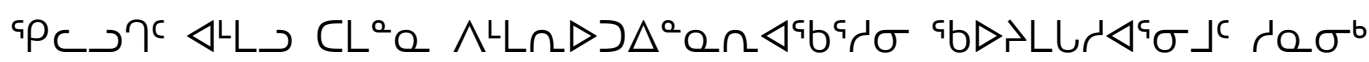

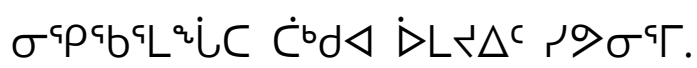

